\title{
Estimates of the Number of Large Amplitude Gusts
}

J. V. Ramsdell

March 1978

Prepared for the

U.S. Department of Energy

under Contract EY-76-C-06-1830 


\title{
NOTICE
}

This report was prepared as an account of work sponsored by the United States Covernment. Neither the United States nor the Department of Energy, nor any of their employees, nor any of their contractors, subcontractors, or their employees, makes any warranty, express or implied, or assumes any legal liability or responsibility for the accuracy, completeness or usefislness of any information, apparatus, produci or process disclosed, or represents that its use would not infringe privately owned rights.

The views, opinions and conclusions contained in this report are those of the contractor and do not necessarily represent those of the United States Government or the United States Department of Energy.

\author{
PACIFIC NORTHW/EST LABORATORY \\ operated by \\ BATTELLE \\ for the \\ UNITED STATES DEP,ARTMENT OF ENERCY \\ Under Contract EY-76-C-06-1830
}

\author{
Printed in the United States of America \\ Avaitable from \\ National Technical Information Service \\ United States Department of Commerce \\ 5285 Port Royal Road \\ Springfield, Virginia 22151
}

Price: Printed Copy \$_; Microfiche $\$ 3.00$

NTIS

- Pages Selling Price

$001-025 \quad \$ 4.50$

$026-050 \quad \$ 5.00$

$051-075 \quad \$ 5.50$

076-100 $\quad \$ 6.00$

$101-125 \quad \$ 6.50$

$126-150 \quad \$ 7.00$

$151.175 \quad \$ 7.75$

$176-200 \quad 58.50$

$201-225 \quad \cdot \quad 58.75$

226-250 $\$ 37.00$

$251-275 \quad \$ 10.00$

$276-300 \quad \$ 10.25$ 
PNL -2508

$\mathrm{UC}-60$

\section{8}

ESTIMATES OF THE NUMBER OF LARGE AMPLITUDE GUSTS

J. V. Ramsdell

Applied Meteorology Section

Atmospheric Sciences Department

March 1978

BATTELLE

PACIFIC NORTHWEST LABORATORY

RICHLAND, WASHINGTON 99352 
.

. 


\section{SUMMARY}

The purpose of this report is to present preliminary estimates of the number of occurrences of large amplitude gusts for use in the design of wind energy conversion systems. Existing turbulence information has been combined with an assumed wind speed distribution to arrive at the estimates.

The number of large amplitude gusts per year is treated as a function of the annual mean wind speed and terrain roughness. This treatment is based upon the assumptions that the atmosphere has neutral stability during high winds and that the gustiness is induced by flow over surface roughness elements. Large gusts during thunderstorms and other severe weather phenomena are not treated.

The results of the study are presented in tabular form as a function of gust amplitude and hourly average wind speed. Tables of estimates are given for terrain varying in roughness from open water to high mountains, and for annual mean wind speeds between 4 and $12 \mathrm{~ms}^{-1}$. Positive and negative gusts are treated separately. 
SUMMARY. . . . . . . . . . . . . . . . . . . . .

FIGURES . . . . . . . . . . . . . . . . . . . . 1 . . . . . . . . .

TABLES . . . . . . . . . . . . . . . . . . . . . iv

INTRODUCTION • • . . . . . . . . . . . . . . . . . I I

WIND DESCRIPTION • . . . . . . . . . . . . . . . . 2

GUST AMPLITUDE EXCEEDANCE ESTIMATES. • . • . . . . . • . . . 5

RESULTS. • • • • • • • • • • • • • • • • • • • • 10

CONCLUSIONS . . . . . . . . . . . . . . . . . . . . 15

REFERENCES . . . . . . . . . . . . . . . . . . . 17

APPENDIX A: GUST EXCEEDANCE TABLES. • • • • . • • • • . . 19 


\section{FIGURES}

1 Relationship between the number of positive gusts and wind speed. . . . . . . . . . 7

2 Number of gusts per hour (positive and negative) exceeding a given amplitude. . . . 8 


\section{TABLES}

1 Relationship between the turbulence

intensity and terrain types. . . . . . . . . . 4

2 Exceedance parameters for seattle turbulence data. . . . . . . . . . . . . . . 9

3 Estimated number of large amplitude gusts for a location in hilly terrain with a $6 \mathrm{~ms}^{-1}$ annual mean wind speed. . . . . . . . 12

4 Estimated number of occurrences per year of gusts exceeding $4 \mathrm{~ms}^{-1}$ (9 mph) when the hourly average wind speed is between 7 and $9 \mathrm{~ms}^{-1}(16$ and $20 \mathrm{mph}) . . . . . . . .13$

5 Estimated number of occurrences per year of gusts exceeding $8 \mathrm{~ms}^{-1}$ (18 $\mathrm{mph}$ ) when the hourly average wind speed is between 15 and $17 \mathrm{~ms}^{-1}(34$ and $38 \mathrm{mph})$. . . . . . . 13

6 Estimated number of occurrences per year of gusts exceeding $12 \mathrm{~ms}^{-1}$ ( $27 \mathrm{mph}$ ) when the hourly average wind speed is between 23 and $25 \mathrm{~ms}^{-1}$ (51 and $56 \mathrm{mph}$ ) . . . . . . . 14 
ESTIMATES OF THE NUMBER OF LARGE AMPLITUDE GUSTS

J. V. Ramsdell

\section{INTRODUCTION}

Consideration of gustiness of the wind is important in the design of structures exposed to the wind. The purpose of this report is to provide preliminary information for estimating the number of gusts exceeding a given amplitude during the life of a structure. In particular it is provided for use in the design of wind energy conversion systems (WECS). The estimated number of large amplitude gusts in a typical year is a function of terrain roughness and annual mean wind speed as well as hourly mean wind speed and gust amplitude. Positive and negative gusts are treated separately.

The analysis leading to the estimates parallels work done to describe gusts experienced by low flying aircraft (250 to $750 \mathrm{ft}$ above ground) in the U.S. Air Force's LO-LOCAT research program (1-3). It combines analysis of turbulence collected downwind of the central business district in seattle, WA and at the Seattle-Tacoma International Airport (4) with turbulence information reported for other locations. The estimates presented are strictly applicable to gustiness resulting from mechanically induced turbulence. Gustiness during thunderstorms and other severe weather phenomena is outside the scope of this study.

The estimated numbers of large amplitude gusts presented in the tables in Appendix $A$ are preliminary in two respects. They are based, to a large degree, on the seattle turbulence data which may not be representative of turbulence in typical sites selected for installation of wind energy conversion systems: And, the form of presentation of the estimates has been developed following limited interaction with wind energy conversion system designers. 
Publication of these preliminary estimates is designed to initiate an interaction between meteorologists and wind system designers. Meteorologists need to know which gust amplitudes are important in design and the frequency of occurrence at which they become important. They also need to know how information on gust amplitudes should be presented to be of maximum value to designers. Comments and suggestions along these lines will play an important role in determining the form revisions to this report will take.

\section{WIND DESCRIPTION}

Although the concept of gusts is generally understood in an intuitive way, formal definition of several concepts facilitates a quantitative understanding necessary to correctly interpret the results presented. We will concern ourselves with wind speed, but the definition can be extended to the full velocity vector without significant alteration. Throughout this report wind specifically refers to the wind at a height above ground of interest. For horizontal axis WECS this height is assumed to be hub height, and for vertical axis wECS the height is assumed to be mid-rotor height.

Under most atmospheric conditions, if we observe the wind for a suitably long period we can define a mean speed, $\bar{U}$, according to

$$
\bar{U}=\frac{1}{T} \int_{0}^{T} U(t) d t
$$

where $U(t)$ is the instantaneous speed and $T$ is the averaging period. We can then define a gust as the departure of the instantaneous wind speed from the mean, i.e.,

$$
u(t)=U(t)-\bar{U}
$$


where $u(t)$ is the amplitude of the gust at $t$. The end of one gust and the beginning of the next are defined by $u(t)=0$; both positive and negative gusts are possible. Finally we define a measure of gustiness, $\sigma_{u}$ ' by

$$
\sigma_{u}=\left[\frac{1}{T} \int_{0}^{T} u^{2}(t) d t\right]^{1 / 2} .
$$

To obtain a more precise definition of $\mathrm{T}$ required in Equations (1) and (3) it is necessary to consider the accuracy desired and problems associated with long T. Following the logic of Wyngaard (5), the average wind speed can be estimated to an accuracy of about $1 \%$ in a 15 minute observation period. However, more than an hour is required to estimate $\sigma_{u}$ to the same accuracy. Thus accuracy considerations lead to measurement for periods as long as possible. The problem associated with long measurement periods is that $U$ and $\sigma_{u}$ may become a function of time. In particular, they may change as a result of the earth's diurnal heating cycle. As a result of these considerations, the choice of $\mathrm{T}$ in the range of 30 to 60 minutes is most realistic.

During the relatively high wind speeds of interest in wind energy conversion the atmospheric stability is approximately neutral. Under these conditions it is reasonable to assume that our measure of gustiness, $\sigma_{u}$, is a function of wind speed and surface roughness. This assumption is supported by data, although the scatter is large and it is difficult to quantify the relationship between $\sigma_{u}$ and surface roughness. sethuRaman, et. al. (6) present data that indicate

$$
\sigma_{\mathrm{u}}=.09 \overline{\mathrm{U}}
$$

for air flow over water in neutral atmospheric conditions, and Maccready, et. al. (7) show turbulence increasing more than four- 
fold from flat desert terrain to high mountains. Finally, Counihan ${ }^{(8)}$ formally suggests a relationship of the form

$$
\sigma_{\mathrm{u}}=\mathrm{k} \overline{\mathrm{U}}
$$

where $\mathrm{k}$ is a function of surface roughness, based on a review of turbulence data published through 1972. The proportionality constant $k$ is also known as the intensity of turbulence.

Turbulence literature shows a tendency of $\mathrm{k}$ to decrease as height above ground and mean wind speed increase. However, for our present purposes we can neglect this variation and adopt Equation (5) assuming a constant $\mathrm{k}$. In addition we assume the relationship between $k$ and terrain given in Table 1 . Table 1. Relationship between the turbulence
intensity and terrain types

\begin{tabular}{ll}
\multicolumn{1}{c}{ Terrain Type } & $\mathrm{k}$ \\
\hline Smooth/Open Water & .10 \\
Flat/Gently Rolling & .15 \\
Hilly & .20 \\
Low Mountains & .25 \\
High Mountains & .30
\end{tabular}

In the foregoingdiscussion, we have assumed neutral atmospheric stability and mechanically generated turbulence. While these are the typical conditions of interest in wind energy conversion, there are other conditions that may be important in wECS design. They include extreme low level atmospheric stability, mountain lee-waves, thunderstorms, and dust devils. The results presented here do not apply to these conditions. 


\section{GUST AMPLITUDE EXCEEDANCE ESTIMATES}

Having completed basic definitions, we now address the central problem under consideration, i.e., estimation of the number of times a structure will experience gusts of a given amplitude in some specified period of time. If we were in a position to wait an extended period of time for our estimates we would perform the following experiment. We would place an anemometer at the location of the proposed structure and record the wind speed continuously. At the end of the period we would divide the record into 1 hour segments and compute $\bar{U}$ and $\sigma$ for each segment. We would then go back through the records and count the number of gusts and the number of times gust amplitudes exceeded some value of interest, $\Delta u$. We would then look for relationship between $\mathrm{N}(\Delta \mathrm{u})$, the number of gusts with amplitudes exceeding $\Delta \mathrm{u} ; \mathrm{N}_{\mathrm{O}}$, the total number of gusts, $\overline{\mathrm{U}}$, and $\sigma_{\mathrm{u}}$. This relationship would then be combined with information on the long term distribution of $\overline{\mathrm{U}}$ to provide the desired estimates.

Not having the luxury of an extended period to make observations at each potential site for installation of wind energy conversion systems, we proceed in an identical manner with available data.

The analysis of the LO-LOCAT turbulence data $(1-3)$ in general supports a relationship of the form

$$
N(\Delta u)=N_{o} \sum_{i=1}^{n} P_{i} e^{-a_{i} x}
$$

for the number of gusts exceeding $\Delta u$ during a flight, where $P_{i}$ is the fraction of the time that turbulence category $i$ is encountered, $a_{i}$ is related to the probability distribution of $u(t)$, and $x$ is $\Delta u / \sigma_{u}$. The mean wind speed does not enter $N(\Delta u)$ explicitly because steady-state aircraft loads are related to 
the mean airspeed of the aircraft rather than the speed of the wind relative to the ground. There is, however, a relationship between $\overline{\mathrm{U}}$ and $\mathrm{a}_{i}$.

The steady-state loads on wind energy conversion systems are a function of mean wind speed. Therefore, it is necessary to identify both mean wind speed and gust amplitude in exceedance estimates. Thus, $\mathrm{N}(\Delta \mathrm{u}, \overline{\mathrm{U}})$ is taken as the number of gusts per unit time with amplitudes exceeding $\Delta u$ when the mean wind speed is $\bar{U}$.

An analysis of gust amplitude data from seattle, wA was used to evaluate the relationship between gust amplitudes, turbulence and the mean wind speed during half-hour periods. The wind measurements were made at heights between 12.7 and $95.4 \mathrm{~m}$ above ground. Mean wind speeds during the measurement periods ranged between 1 and $14 \mathrm{~ms}^{-1}$. The measurements are described in detail in Reference 4.

When the gust data from seattle were analyzed, it was determined that $\mathrm{N}_{\mathrm{o}}$ was independent of mean wind speed, and had a mean value of about $1150 \mathrm{hr}^{-1}$. Figure 1 shows that the number of positive gusts per kilometer of air passage is proportional to the inverse of the mean wind speed. The actual value of $\mathrm{N}_{0}$ is a function of measurement system dimensions and would be lower for larger measurement systems. In addition it may be a function of the terrain roughness.

It was further determined that for the seattle data the relationship between $\mathrm{N}(\Delta \mathrm{u}, \overline{\mathrm{U}}), \mathrm{N}_{\mathrm{O}}$ and $\Delta \mathrm{u} / \sigma_{\mathrm{u}}$ was described by an exponential of the form:

$$
\mathrm{N}(\Delta \mathrm{u}, \overline{\mathrm{U}}) / \mathrm{N}_{\mathrm{O}}=\exp \left(-\mathrm{ax} \mathrm{x}^{\mathrm{b}}\right)
$$

where $\mathrm{x}$ is $\Delta \mathrm{u} / \sigma_{\mathrm{u}}$. Figure 2 shows the relationships for both positive and negative gusts assuming $\mathrm{N}_{0}=1150 \mathrm{hr}^{-1}$. The data points shown represent average values of $N(\Delta u, \bar{U})$ for small ranges of $\Delta u / \sigma_{u}$. 


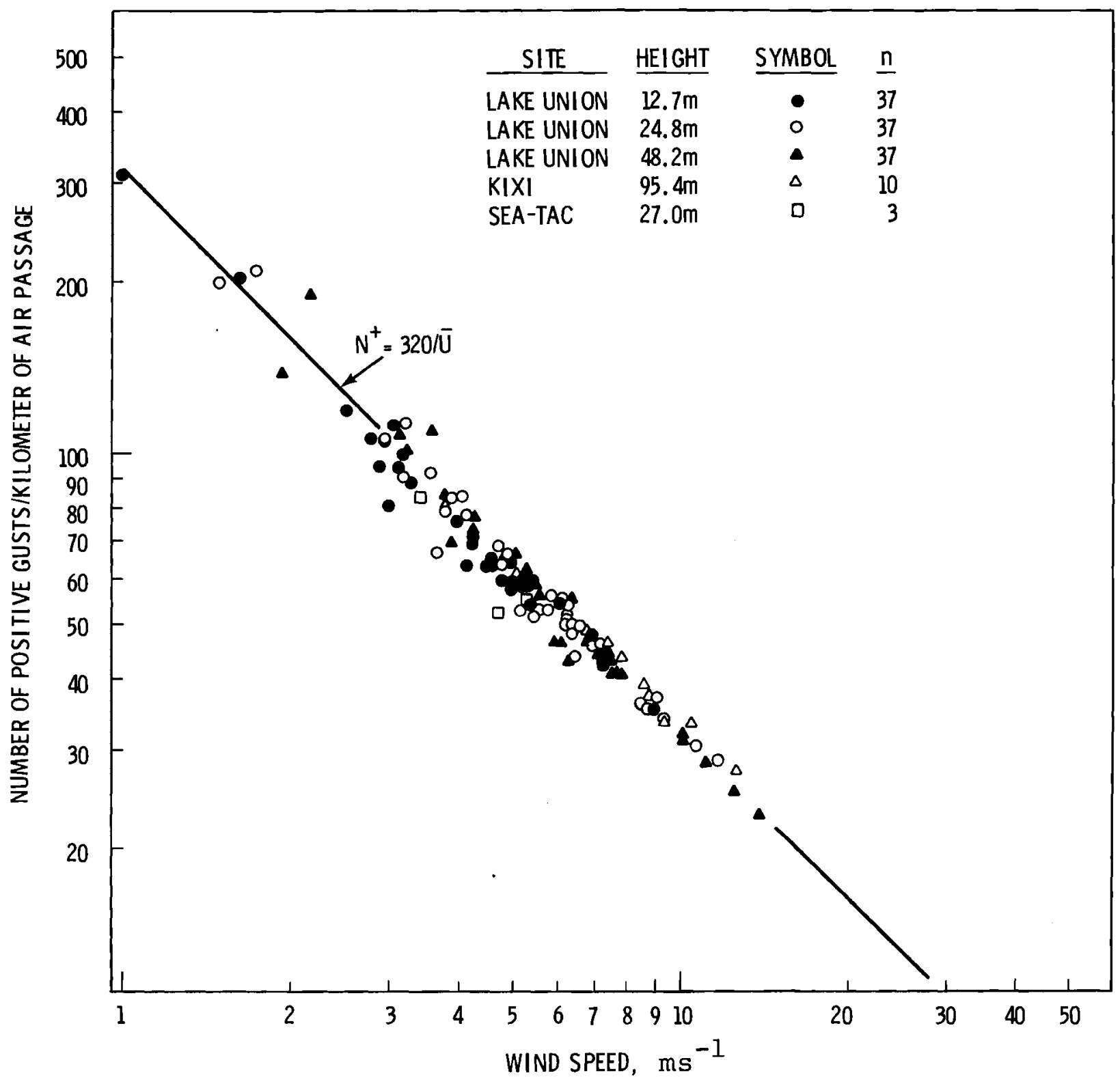

Figure 1. Relationship between the number of positive gusts and wind speed. 

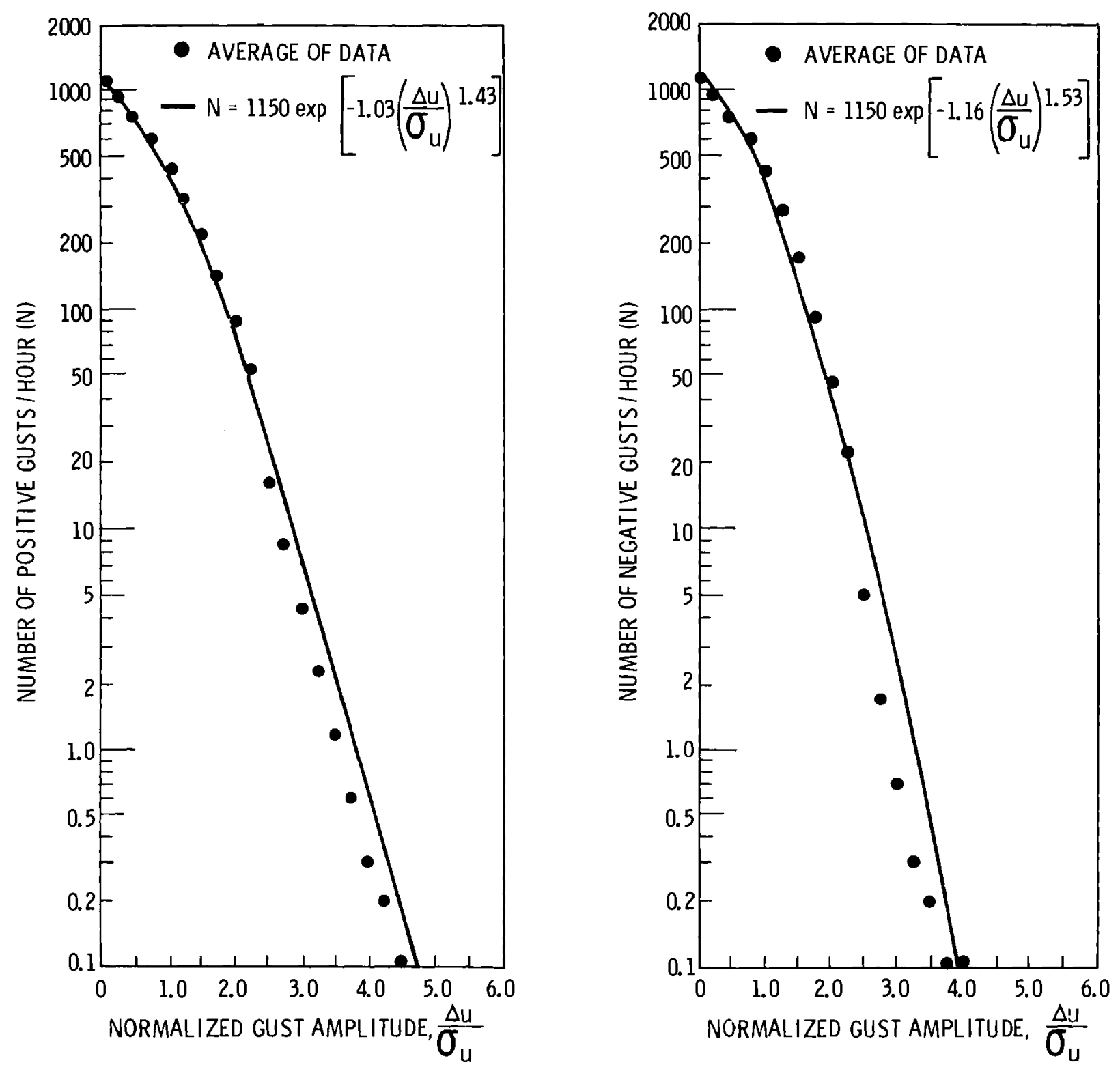

Figure 2. Number of gusts per hour (positive and negative) exceeding a given amplitude. 
The values of $a$ and $b$ determined for these data using linear regression techniques are given in Table 2. The differences between the values for positive and negative gusts are statistically significant. As a result they are treated separately throughout this report.

\section{Table 2. Exceedance parameters for Seattle turbulence data}

$\begin{array}{ccc} & a & b \\ \text { Positive Gusts } & 1.03 & 1.43 \\ \text { Negative Gusts } & 1.16 & 1.53\end{array}$

The results presented in Equation (7) and Table 2 are specific to the seattle data, and their application to other locations is open to question. However, in order to provide preliminary estimates of the number of occurrences of large amplitude gusts, we will use these results in conjunction with the results of turbulence research at other locations.

At this point estimation of the number of large amplitude gusts requires the specification of hourly mean wind speed and a qualitative knowledge of the terrain in the area of interest. The remaining task is specification of the frequency of occurrence of each wind speed. Doran, et. al. (9) discuss wind speed probability distributions and conclude that for wind energy applications a Rayleigh distribution is an acceptable approximation. One advantage of the Rayleigh distribution is that it is completely determined when the annual mean wind speed is specified.

Using this distribution, the number of hours per year that the wind speed is between $c_{1}$ and $c_{2}$ is given by 


$$
\mathrm{F}\left(\mathrm{C}_{1} \leq \mathrm{U} \leq_{\mathrm{C}_{2}}\right)=8766\left\{\exp \left[-\frac{\pi}{4}\left(\frac{\mathrm{C}_{1}}{\overline{\mathrm{V}}}\right)^{2}\right]-\exp \left[-\frac{\pi}{4}\left(\frac{\mathrm{C}_{2}}{\overline{\mathrm{V}}}\right)^{2}\right]\right\}
$$

where $\bar{V}$ is the annual mean speed.

Cliff(10) presents comparisons of the observed wind speed frequency distributions at 16 locations with the appropriate Rayleigh approximations. These comparisons show that the Rayleigh distribution tends to underestimate the frequency of moderate wind speeds and overestimate the frequency of high wind speeds. However, the differences noted do not significantly affect the utility of the Rayleigh distribution for planning and design studies.

Therefore, we end up with an estimate of the number of gusts per year exceeding $\Delta u$ of the form

$$
\mathrm{N}(\Delta \mathrm{u}, \overline{\mathrm{U}})=1150 \mathrm{~F}\left(\mathrm{c}_{1} \leq \overline{\mathrm{U}} \mathrm{sc}_{2}\right) \exp \left(-\mathrm{ax} \mathrm{x}^{\mathrm{b}}\right)
$$

The number of gusts of amplitude $\Delta u$ when the hourly mean speed is $\bar{U}$ experienced during the service life of the wind system can be found by simply multiplying $N(\Delta u, \bar{U})$ from Equation (9) by the expected life in years.

\section{$\underline{\text { RESULTS }}$}

Equations (5), (7), (8) and (9) form a set that can be used to estimate the number of large amplitude gusts at a site if the annual mean wind speed and terrain classification are known. These computations have been carried out for each of five terrain classifications and for annual mean wind speeds between 4 and $12 \mathrm{~ms}^{-1}$ ( 9 and $27 \mathrm{mph}$ ). The results of the computations are presented in Appendix A for gust amplitudes between - 10 and $+12 \mathrm{~ms}^{-1}$ (-22 and $+27 \mathrm{mph}$ ) and hourly average wind speeds between 2 and $30 \mathrm{~ms}^{-1}$ (4.5 and $67 \mathrm{mph}$ ). 
Table 3 shows an example of the computational results for a typical location which might be considered for a WECS installation. In the table, values of $\mathrm{N}(\Delta \mathrm{u}, \overline{\mathrm{U}})$ are given as a function of $\Delta u$ and $\bar{U}$. In reality, $\bar{U}$ is the center of a $2 \mathrm{~ms}^{-1}$ range, i.e., $10 \mathrm{~ms}^{-1}$ represents the range 9 to $11 \mathrm{~ms}^{-1}$. It should also be remembered that $\mathrm{N}(\Delta \mathrm{u}, \overline{\mathrm{U}})$ is the number of gusts exceeding $\Delta \mathrm{u}$. Values of $\mathrm{N}(\Delta \mathrm{u}, \overline{\mathrm{U}})$ less than $0.1 \mathrm{yr}^{-1}$ are not included in Table 3 or in the tables in Appendix A.

The variation of gust estimates with terrain classification and annual mean wind speed is shown in Tables 4 through 6 . Table 4 is for an hourly average speed near the low end of a typical wECS operating range, and Tables 5 and 6 are for average wind speeds near the high speed end. In each table the gust amplitude examined is approximately half of the average speed. In general, Tables 4 through 6 show that the estimated number of gusts of a given amplitude becomes less sensitive to changes in annual mean wind speed or terrain classification as the wind speed and terrain roughness increase.

Table 4 shows that the number of gusts of a given amplitude reaches a maximum as the annual mean wind speed increases, and then decreases with further increases in mean speed. The rate of increase is rapid at low speeds and is generally more rapid than the decrease at high speeds. This behavior follows from the shape of the frequency distribution of hourly average speeds and the change of the distribution with changes in annual mean speeds. As expected, the number of gusts of a given amplitude also increases with increasing terrain roughness. This increase results from the decrease in the ratio $\Delta u / \sigma_{u}$ as $\sigma_{u}$ becomes a larger proportion of $\overline{\mathrm{U}}$.

Tables 5 and 6 show the increase in number of gusts with increasing annual mean speed, but they do not show the maximum. The hourly average speeds considered in these tables are sufficiently high that the maximums occur at annual mean speeds above $12 \mathrm{~ms}^{-1}$. 
Table 3. Estimated number of large amplitude gusts for a location in hilly terrain with a $6 \mathrm{~ms}^{-1}$ annual mean wind speed.

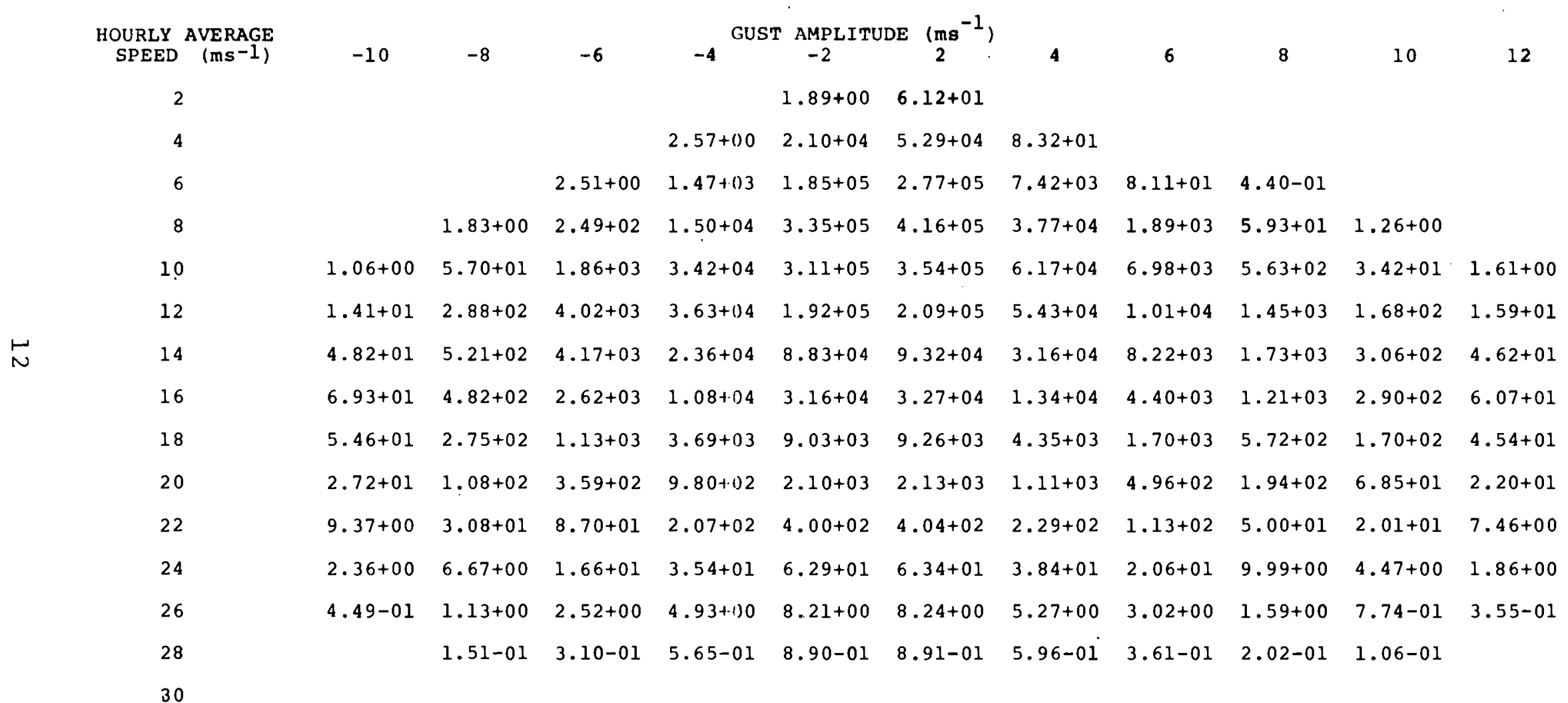


Table 4. Estimated number of occurrences per year of gusts exceeding $4 \mathrm{~ms}^{-1}$ (9 mph) when the hourly average wind speed is between 7 and $9 \mathrm{~ms}^{-1}$ (16 and $20 \mathrm{mph}$ ).

\begin{tabular}{lccccc} 
& \multicolumn{4}{c}{ ANNUAL MEAN WIND } & SPEED \\
Terrain & 4 & 6 & 8 & 10 & 12 \\
Open Water & $2.5+01$ & $5.9+01$ & $6.1+01$ & $5.2+01$ & $4.2+01$ \\
Flat Land & $2.2+03$ & $5.4+03$ & $5.6+03$ & $4.8+03$ & $3.8+03$ \\
Hilly & $1.6+04$ & $3.8+04$ & $3.9+04$ & $3.3+04$ & $2.7+04$ \\
Low Mts. & $4.4+04$ & $1.1+05$ & $1.1+05$ & $9.4+04$ & $7.6+04$ \\
High Mts. & $8.4+04$ & $2.0+05$ & $2.1+05$ & $1.8+05$ & $1.4+05$
\end{tabular}

Table 5. Estimated number of occurrences per year of gust exceeding $8 \mathrm{~ms}^{-1}$ (18 mph) when the hourly average wind speed is between 15 and $17 \mathrm{~ms}^{-1}$ ( 34 and $38 \mathrm{mph}$ ).

ANNUAL MEAN WIND SPEED

\begin{tabular}{lccccc}
\multicolumn{1}{c}{ Terrain } & 4 & 6 & 8 & 10 & 12 \\
Open Water & $*$ & $1.9+00$ & $1.2+01$ & $2.3+01$ & $3.0+01$ \\
Flat Land & $4.8-01$ & $1.7+02$ & $1.1+03$ & $2.1+03$ & $2.7+03$ \\
Hilly & $3.3+00$ & $1.2+03$ & $7.5+03$ & $1.5+04$ & $1.9+04$ \\
Low Mts. & $9.5+00$ & $3.4+03$ & $2.1+04$ & $4.2+04$ & $5.4+04$ \\
High Mts. & $1.8+01$ & $6.5+03$ & $4.0+04$ & $7.9+04$ & $1.0+05$
\end{tabular}

*1ess than 0.1 
Table 6. Estimated number of occurrences per year of gusts exceeding $12 \mathrm{~ms}^{-1}$ ( $27 \mathrm{mph}$ ) when the hourly average wind speed is between 23 and $25 \mathrm{~ms}^{-1}$ ( 51 and $56 \mathrm{mph}$ ).

ANNUAL MEAN WIND SPEED

\begin{tabular}{lccccc}
\multicolumn{1}{c}{ Terrain } & 4 & 6 & 8 & 10 & 12 \\
Open Water & $*$ & $*$ & $3.6-01$ & $2.8+00$ & $7.8+00$ \\
Flat Land & $*$ & $2.7-01$ & $3.3+01$ & $2.6+02$ & $7.2+02$ \\
Hilly & $*$ & $1.9+00$ & $2.3+02$ & $1.8+03$ & $5.0+03$ \\
Low Mts. & $*$ & $5.3+00$ & $6.5+02$ & $5.2+03$ & $1.4+04$ \\
High Mts. & $*$ & $1.0+01$ & $1.2+03$ & $9.7+03$ & $2.7+04$ \\
& & $*$ & &
\end{tabular}

The number of gusts of a given amplitude is directly related to $\mathrm{N}_{0}$ assumed in for use in Equation (5). The value $1150 \mathrm{hr}^{-1}$ assumed earlier leads to an upper limit of $10^{7}$ positive and negative gusts per year. Further, this limit should be approached as $\Delta u$ becomes small and $\sigma_{u}$ becomes large, if the wind speed dependence is eliminated, i.e.,

$$
\Delta u \lim _{\tilde{U}} \rightarrow 0 \sum_{\bar{U}} N(\Delta u, \bar{U})=10^{7} .
$$

A check of the estimates for $\Delta u=2 \mathrm{~ms}^{-1}$ in Table A-25 $\left(\Delta u / \sigma_{u}=0.56\right)$ shows the summation in Equation (9) to be about $5.4 \times 10^{6}$.

If the value of $\mathrm{N}_{0}$ in Equation (5) were to be changed by a factor of 2, all estimates in Tables 3 through 6 and $A-1$ through A-25 would be changed by a factor of 2. This factor of 2 change is small in comparison with many of the differences in the estimates in Tables 4 through 6 as a result of changing terrain classification by a single category. In addition at low annual mean wind speeds a change of $2 \mathrm{~ms}^{-1}$ can produce 
changes in the estimates which are larger than those from a factor of 2 change in $\mathrm{N}_{\mathrm{O}}$.

\section{CONCLUSIONS}

The estimated number of occurrences of large amplitude gusts presented in Tables 3 through 6 and Tables A-1 through A-25 are preliminary estimates based on detailed analysis of a limited amount of data. The analysis is supported by conclusions drawn from other studies of atmospheric turbulence. An attempt has been made to present realistic estimates of the number of occurrences of these gusts. However in some instances assumptions have been made which may tend to result in overestimates of the gust occurrences, and in other cases assumptions were made out of necessity. In these cases the resulting biases are unknown.

Assumptions that may tend to bias the estimates toward high values include the assumptions that: $\mathrm{N}_{\mathrm{O}}=1150 \mathrm{hr}^{-1}, \mathrm{k}$ is constant, and that hourly average wind speeds have a Rayleigh distribution.

Assumptions that have an unknown effect on the estimates include both the form of Equation (7) and the values of its numerical coefficients. In comparison with a Gaussian representation, Equation (7) produces the larger estimates, but the Gaussian distribution may underestimate the frequency of large gusts $^{(11)}$.

Following evaluation of the estimates presented in this report by design engineers, revisions, if warranted, should include analysis of additional turbulence data to improve the assumptions listed above.

If it becomes necessary to estimate the number of large amplitude gusts at a specific site, the estimates can be improved by utilizing available data rather than assumptions 
or by making more detailed assumptions. In particular, terrain roughness (and intensity of turbulence) can be treated as a function of wind direction. 
REFERENCES

1. J. A. Dutton and G. J. Thompson: Probabilistic Determination of Aircraft Response to Turbulence at Low Altitudes, A SD-TR-68-39, Āir Force Systems Command, Wright-Patterson Air Force Base, $\mathrm{OH}, 1968,163 \mathrm{p}$.

2. J. W. McCloskey, J. K. Luers, J. P. Ryan and N. A. Engler: Statistical Analysis of LO-LOCAT Turbulence Data for Use in the Development of Revised Gust Griteria, AFFDL-TR-71-29, Air Force Flight Dynamics Laboratory, Wright-Patterson Air Force Base, OH, 1971, 140 p.

3. R. L. Neulieb, J. N. Garrison and D. J. Golden: Atmospheric Turbulence Field Parameters Determination, AFFDL-TR-72-5I, Air Force Flight Dynamics Laboratory, Wright-Patterson Air Force Base, $\mathrm{OH}, 1972,44 \mathrm{p}$.

4. J. V. Ramsdell: Wind and Turbulence Information For Vertical and Short Take-off and Landing (V/STOL) Operations in BuiltUp Urban Areas - Results of Meteorological Survey, FAA-RD-75-94, U.S. Department of Transportation, 1975, 421 p.*

5. J. C. Wyngaard: "On Surface-Layer Turbulence," in Workshop on Micrometeorology, D. A. Haugen, ed., American MeEteorological society, 1973, 392 p.

6. S. SethuRaman, R. M. Brown, J. Tichler: "Spectra of Atmospheric Turbulence Over the Sea During Stably stratified Conditions," in Preprint Volume, Symposium on Atmospheric Diffusion and Air Pollution, September 1974, Santa Barbara, CA. Sponsored by the American Meteorological Society.

7. P. B. MacCready, Jr., L. B. Baboolal and P.B.S. Lissaman: "Diffusion and Turbulence Aloft Over Complex Terrain," Preprint Volume, Sympsoium on Atmospheric Diffusion and Air Pollution, September 1974, Santa Barbara, CA. Sponsored by the American Meteorological Society.

8. J. Counihan: "Adiabatic Atmospheric Boundary Layers: A Review and Analysis of the Data From the Period 1880-1972," Atmospheric Environment, 9:871-905, 1975.

9. J. C. Doran, J. A. Bates, P. J. Liddell and T. D. Fox: Accuracy of Wind Power Estimates, PNL-2442, Battelle, Pacific Northwest Laboratories, Richland, WA 99352, 1977, $26 \mathrm{p}$.* 
10. W. C. Cliff: The Effect of Generalized Wind Characteristics on Annual Power Estimates from Wind Turbine Generators, PNL-2436, Battelle, Pacific Northwest Laboratories, Richland, WA $99352,1977,55$ p.*

11. V. M. Ganzer, R. G. Joppa and G. Van der Wees: Analysis of Low Altitude Atmospheric Turbulence Data Measured in Flight, NASA-CR-2886, September 1977, $108 \mathrm{p}$.

* Available from the National Technical Information Service, Springfield, VA 22161. 
Appendix A

GUST EXCEEDANCE TABLES 


\section{GUST EXCEEDANCE TABLES}

The tables presented in this appendix contain estimates of $N(\Delta u, \bar{U})$, the number of times per year that gust amplitudes will exceed $\Delta u$ when the hourly mean wind speed is $\bar{U}$. These estimates were computed using

$$
\begin{gathered}
N(\Delta \mathrm{u}, \overline{\mathrm{U}})=1150 \mathrm{~F}\left(\mathrm{c}_{1} \leq \overline{\mathrm{U}} \leq \mathrm{c}_{2}\right) \exp \left(-\mathrm{ax}^{\mathrm{b}}\right), \\
\mathrm{F}\left(\mathrm{c}_{1} \leq \overline{\mathrm{U}} \mathrm{C}_{2}\right)=8766\left\{\exp \left[-\frac{\pi}{4}\left(\frac{\mathrm{C}_{1}}{\overline{\mathrm{V}}}\right)^{2}\right]-\exp \left[-\frac{\pi}{4}\left(\frac{\mathrm{c}_{2}}{\overline{\mathrm{V}}}\right)^{2}\right]\right\},
\end{gathered}
$$

and

$$
\mathrm{x}=\Delta \mathrm{u} / \sigma_{\mathrm{u}}=\Delta \mathrm{u} /(\mathrm{k} \overline{\mathrm{U}})
$$

where: $c_{1}$ and $c_{2}$ define a range for hourly wind speeds, $\bar{V}$ is the annual mean speed; and $\sigma_{u}$ is a measure of the gustliness. The values of $a, b$ and $k$ are given in Tables 1 and 2 of the text. Wind speeds used in Equations $A 1$ through $A 3$ are for wind energy conversion system hub height.

To find the proper estimate for a particular application, first select the Table that corresponds to the terrain and annual mean wind speed of interest. For example, Table A-6 might be selected if gusts in the Kansas plains were of interest and the annual average wind speed was found to be about $4 \mathrm{~ms}^{-1}$ ( $\left.8.9 \mathrm{mph}\right)$. The table shows that gusts of $2 \mathrm{~ms}^{-1}$ or larger during periods when the average wind speed is $10 \mathrm{~ms}^{-1}$ are estimated to occur about $3.4 \times 10^{4}$ times per year. Note that $3.39+04$ in table is read as $3.39 \times 10^{4}$. During a 30 year life time it is estimated that a wind energy conversion system would be subjected to about $10^{6}$ gusts of this magnitude.

The tables to not provide any information on the rate at which the wind speed increases or the duration of gusts. 
TABLE $A-1$

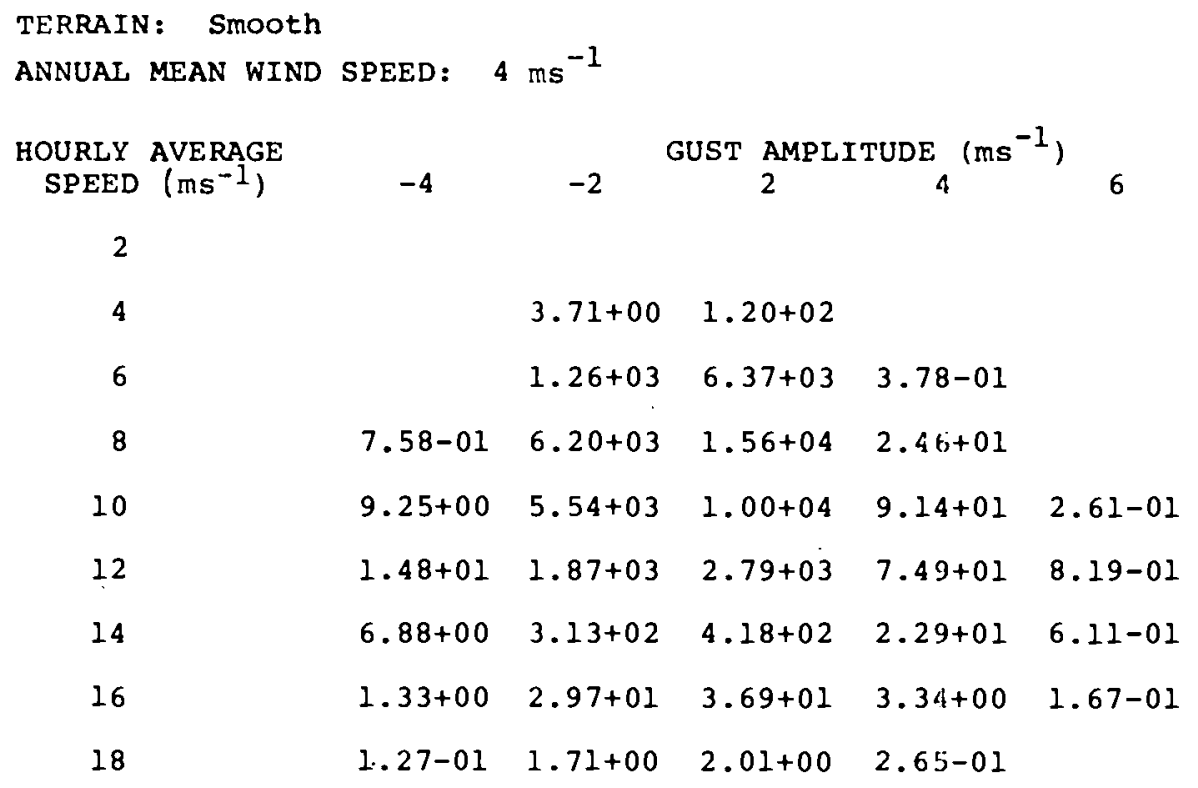


TABLE A-2

TERRAIN : Smooth

ANNUAL MEAN WIND SPEED: $6 \mathrm{~ms}^{-1}$

\begin{tabular}{|c|c|c|c|c|c|c|c|c|c|}
\hline \multirow{2}{*}{$\begin{array}{l}\text { HOURLY AVERAGE } \\
\text { SPEED }\left(\mathrm{ms}^{-1}\right)\end{array}$} & \multicolumn{9}{|c|}{ GUST AMPLITUDE $\left(\mathrm{ms}^{-1}\right)$} \\
\hline & -8 & -6 & -4 & -2 & 2 & 4 & 6 & 8 & 10 \\
\hline \multicolumn{10}{|l|}{2} \\
\hline 4 & & & & $2.57+00$ & $8.32+01$ & & & & \\
\hline 6 & & & & $1.47+03$ & $7.42+03$ & $4.40-01$ & & & \\
\hline 8 & & & $1.83+00$ & $1.50+04$ & $3.77+04$ & $5.93+01$ & & & \\
\hline 10 & & & $5.70+01$ & $3.42+04$ & $6.17+04$ & $5.63+02$ & $1.61+00$ & & \\
\hline 12 & & $4.92-01$ & $2.88+02$ & $3.63+04$ & $5.43+04$ & $1.45+03$ & $1.59+01$ & & \\
\hline 14 & & $3.40+00$ & $5.21+02$ & $2.36+04$ & $3.16+04$ & $1.73+03$ & $4.62+01$ & $7.01-01$ & \\
\hline 16 & & $8.00+00$ & $4.82+02$ & $1.08+04$ & $1.34+04$ & $1.21+03$ & $6.07+01$ & $1.91+00$ & \\
\hline 18 & $1.49-01$ & $9.00+00$ & $2.75+02$ & $3.69+03$ & $4 \cdot 35+03$ & $5.72+02$ & $4.54+01$ & $2.44+00$ & \\
\hline 20 & $1.80-01$ & $5.87+00$ & $1.08+02$ & $9.80+02$ & $1.11+03$ & $1.94+02$ & $2.20+01$ & $1.78+00$ & $1.08-01$ \\
\hline 22 & $1.23-01$ & $2.49+00$ & $3.08+01$ & $2.07+02$ & $2.29+02$ & $5.00+01$ & $7.46+00$ & $8.29-01$ & \\
\hline 24 & & $7.40-01$ & $6.67+00$ & $3.54+01$ & $3.84+01$ & $9.99+00$ & $1.86+00$ & $2.68-01$ & \\
\hline 26 & & $1.61-01$ & $1.13+00$ & $4.93+00$ & $5.27+00$ & $1.59+00$ & $3.55-01$ & & \\
\hline 28 & & & $1.51-01$ & $5.65-01$ & $5.96-01$ & $2.02-01$ & & & \\
\hline
\end{tabular}


TABLE A-3

TERRAIN: Smooth

ANNUAL MEAN WIND SPEED: $8 \mathrm{~ms}^{-1}$

HOURLY AVERAGE

SPEED $\left(\mathrm{ms}^{-1}\right)$

4

10

$N$

$1.07+00$

$6.27+02$

$7.89+04$
$-10 \quad-8$

$-6$

$-4$

$\underset{-2}{\operatorname{GUST}} \begin{array}{cr}\text { AMPLITUDE } & \left(\mathrm{ms}^{-1}\right) \\ 4 & \end{array}$

6

8

10

12

$1.69+00 \quad 5.48+01$

$1.17+03 \quad 5.90+03 \quad 3.49-01$

$1.89+00 \quad 1.54+04 \quad 3.89+04 \quad 6.11+01$

$8.23+01 \quad 4.94+04 \quad 8.90+04 \quad 8.13+02 \quad 2.32+00$

$1.20+01$

$1.18+05$

$3.17+03$

$3.46+01 \quad 1.88-01$

14

16

3. 65-01

$4.95+01$

$1.84+03$

8. $36+04$

$1.12+05 \quad 6.12+03$

$1.63+02$

$2.48+00$

$1.75+00 \quad 1.05+02$

$.98+03$

$6.68+0$

$7.52+03$

$3.76+02$

$1.18+01 \quad 2.50-01$

$4.27+00 \cdot 1.40+02$

$3.22+03$

$4.31+04 \quad 5.08+04 \quad 6.68+03$

$5.31+02$

$2.85+01 \quad 1.10+00$

20

22

2.03-01

$6.38+00 \quad 1.30+02$

$2.56+03$

$2.33+04$

$2.65+04$

$4.62+03$

$5.23+02$

$4.22+01$

$2.56+00$

1.21-01

$3.20-01$

$6.53+00$

$9.10+013.21+02$

$1.08+04$

$1.20+04 \quad 2.60+03$

$3.89+02$

$4.32+01 \quad 3.74+00$

2.60-01

3. 41-01

4. $91+00$

$5.05+01$

$3.53+02$

$1.55+0$

$4.73+03$

$1.23+03$

$2.29+02$

$3.29+01 \quad 3.80+00$

3. 60-01

2. 65-01

$2.87+00$

$2.29+01$

1. $30+02$

$4.86+02$

$4.97+02$

$1.11+02$

$1.97+01$

$2.86+00$

3. 50-01

$1.58-01 \quad 1.34+00$

$8.73+00$

$4.16+01$

$1.36+02-1.42+02 \quad 5.34+01$

$4 \cdot 52+01$

$9.53+00 \quad 1.68+00$

2. 54-01

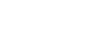


TABLE A-4

TERRAIN: Smooth

ANNUAL MEAN WIND SPEED: $10 \mathrm{~ms}^{-1}$

\section{HOURLY AVERAGE}

SPEED (ms-1)

2

4

6

8

10

12 
TABLE $A-5$

TERRAIN : Smooth

ANNUAL MEAN WIND SPEED: $12 \mathrm{~ms}^{-1}$

HOURLY AVERAGE

SPEED ( $\left.\mathrm{ms}^{-1}\right)$

2

4

6

8

10

12

14

16

18

20

22

24

26

28

30

$-10$

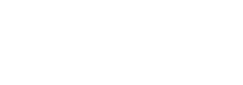

$-8-6$

$-4$

$7.23+01$

1. $26+00$

$2.02+01 \quad 3.09+03$

\subsection{6-01}

$6.93+00$

1. $24+02$

$7.49+03$

5. 24-01

$4.18+02$

1. $28+04$

$1.71+05$

L. $70+04$

1. $54+05$

$2.37+00$

$7.45+01$

$1.51+03$

1. $87+04$

$6.94+00$

$1.42+02$

$1.45+01$

$2.09+02$

1. $78+04$

$2.34+01$

$2.53+02 \quad 2.02+03$

l. $15+04$

4.2

$3.04+01$

$2.59+02 \quad 1.68+03$

$8.01+03$ $\left.\underset{-2}{\text { GUST AMPLITUDE }} \quad \mathrm{ms}^{-1}\right)_{4}$

$8.44-01 \quad 2.73-01$

$6.66+02 \quad 3.36+03 \quad 1.99-01$

$1.30+00 \quad 1.06+04 \quad 2.68+04 \quad 4.21+01$

$4.33+04 \quad 7.82+04 \quad 7.14+02$

$9.32+04 \quad 1.40+05$

$3.74+03$

$4.09+01 \quad 2.22-01$

$1.87+05$

$1.03+04$

$2.74+02 \quad 4.16+00$

$2.08+05$

$1.89+04$

$2.65+04$

$9.45+02$

$2.97+01$

$2.02+05$

$1.76+05$

3. $06+04$

$2.11+03$

$1.13+02$

6. 29-01

$1.26+05 \quad 1.39+05$

$3.04+04$

$.47+03$

$2.80+02$

$4.35+001.25-01$

$9.45+04 \quad 1.03+05$

$2.67+04$

$4.54+03$

$5.04+02$

$1.70+017.99-01$

$2.62+04$

$7.03+04$

$2.12+04$

$4.98+03$

$7.15+02$

$4.37+01 \quad 3.04+00$

$\begin{array}{llll}.73+03 & 8.38+02 & 1.22+02 & 1.49+01\end{array}$

$3.99+03 \quad 8.40+02 \quad 1.48+02 \quad 2.24-01$

$\begin{array}{lll}7.40+02 & 1.54+02 \quad 2.77+01\end{array}$ 
TABLE $A-6$

TERRAIN: Flat/Gently Rolling ANNUAL MEAN WIND SPEED: $4 \mathrm{~ms}^{-1}$

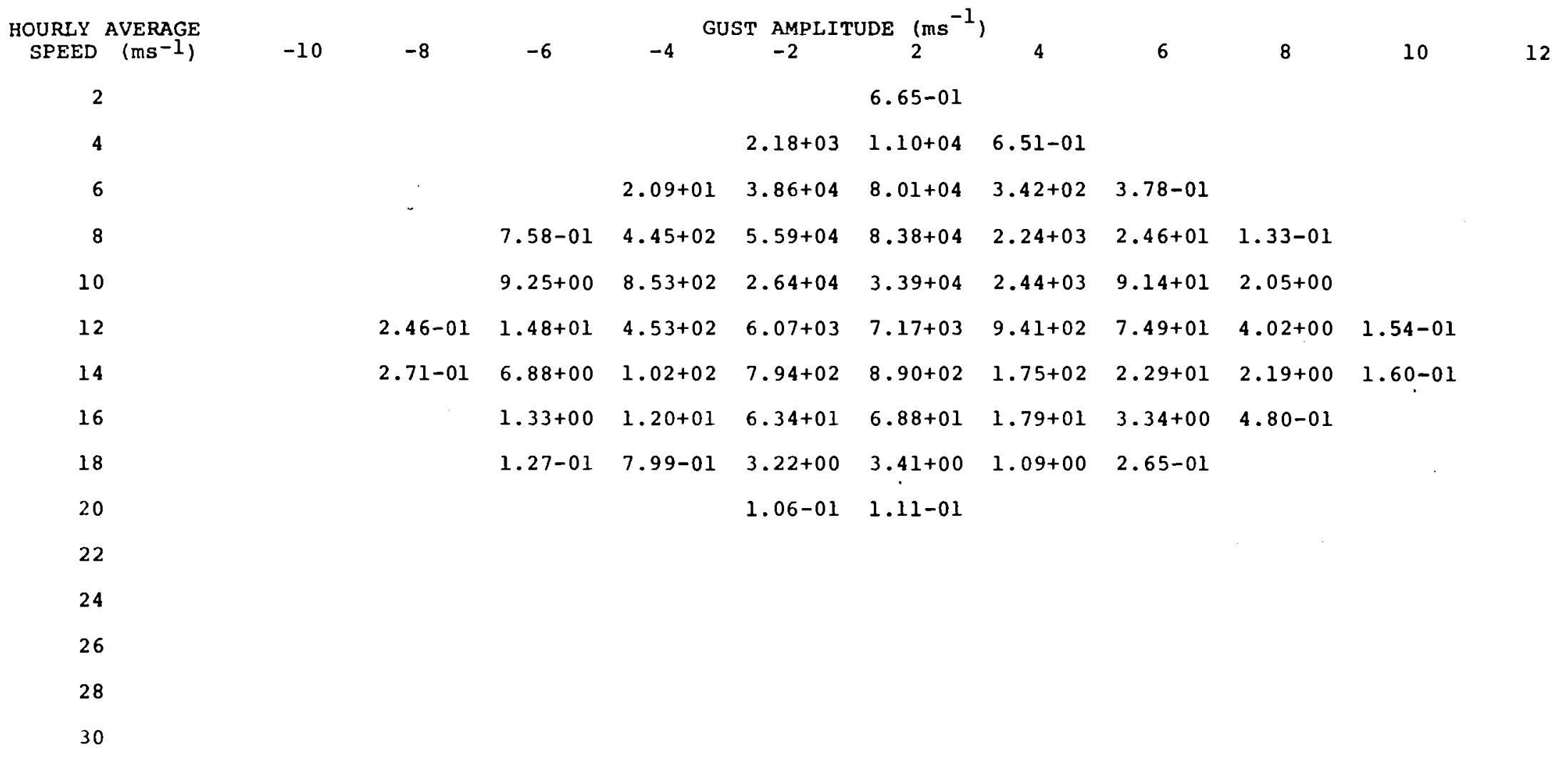




\section{TABLE A-7}

TERRAIN: Flat/Gently Rolling ANNUAL MEAN WIND SPEED: $6 \mathrm{~ms}^{-1}$

\begin{tabular}{|c|c|c|c|c|c|c|c|c|c|c|c|}
\hline $\begin{array}{l}\text { HOURLY AVERAGE } \\
\text { SPEED }\left(\mathrm{ms}^{-1}\right)\end{array}$ & -10 & -8 & -6 & -4 & ST AMPLI' & UDE $2^{\left(\mathrm{ms}^{-1}\right.}$ & 4 & 6 & 8 & 10 & 12 \\
\hline 2 & & & & & & $3.32-01$ & & & & & \\
\hline 4 & & & & & $1.51+03$ & $7.60+03$ & $4.51-01$ & & & & \\
\hline 6 & & & & $2.44+01$ & $4.50+04$ & $9.33+04$ & $3.98+02$ & $4.40-01$ & & & \\
\hline 8 & & & $1.83+00$ & $1.07+03$ & $1.35+05$ & $2.02+05$ & $5.42+03$ & $5.93+01$ & $3.21-01$ & & \\
\hline 10 & & $2.52-01$ & $5.70+01$ & $5.26+03$ & $1.63+05$ & $2.09+05$ & $1.50+04$ & $5.63+02$ & $1.27+01$ & $1.85-01$ & \\
\hline 12 & & $4.78+00$ & $2.88+02$ & $8.81+03$ & $1.18+05$ & $1.39+05$ & $1.83+04$ & $1.45+03$ & $7.80+01$ & $3.00+00$ & \\
\hline 14 & $5.06-01$ & $2.05+01$ & $5.21+02$ & $7.74+03$ & $6.00+04$ & $6.73+04$ & $1.32+04$ & $1.73+03$ & $1.65+02$ & $1.21+01$ & $7.01-01$ \\
\hline 16 & $1.69+00$ & $3.46+01$ & $4.82+02$ & $4.35+03$ & $2.31+04$ & $2.50+04$ & $6.51+03$ & $1.21+03$ & $1.74+02$ & $2.01+01$ & $1.91+00$ \\
\hline 18 & $2.46+00$ & $3.05+01$ & $2.75+02$ & $1.73+03$ & $6.95+03$ & $7.38+03$ & $2.36+03$ & $5.72+02$ & $1.11+02$ & $1.78+01$ & $2.44+00$ \\
\hline 20 & $1.95+00$ & $1.66+01$ & $1.08+02$ & $5.14+02$ & $1.68+03$ & $1.76+03$ & $6.59+02$ & $1.94+02$ & $4.74+01$ & $9.84+00$ & $1.78+00$ \\
\hline 22 & $9.61-01$ & $6.11+00$ & $3.08+01$ & $1.19+02$ & $3.30+02$ & $3.41+02$ & $1.45+02$ & $5.00+01$ & $1.46+01$ & $3.70+00$ & $8.29-01$ \\
\hline 24 & $3.21-01$ & $1.62+00$ & $6.67+00$ & $2.17+01$ & $5.32+01$ & $5.45+01$ & $2.56+01$ & $9.99+00$ & $3.37+00$ & $1.00+00$ & $2.68-01$ \\
\hline 26 & & $3.23-01$ & $1.13+00$ & $3.20+00$ & $7.07+00$ & $7.20+00$ & $3.67+00$ & $1.59+00$ & $6.01-01$ & $2.04-01$ & \\
\hline 28 & & & $1.51-01$ & $3.84-01$ & $7.79-01$ & $7.90-01$ & $4.31-01$ & $2.02-01$ & & & \\
\hline
\end{tabular}


TABLE A-8

TERRAIN: Flat/Gently Rolling ANNUAL MEAN WIND SPEED: $8 \mathrm{~ms}^{-1}$

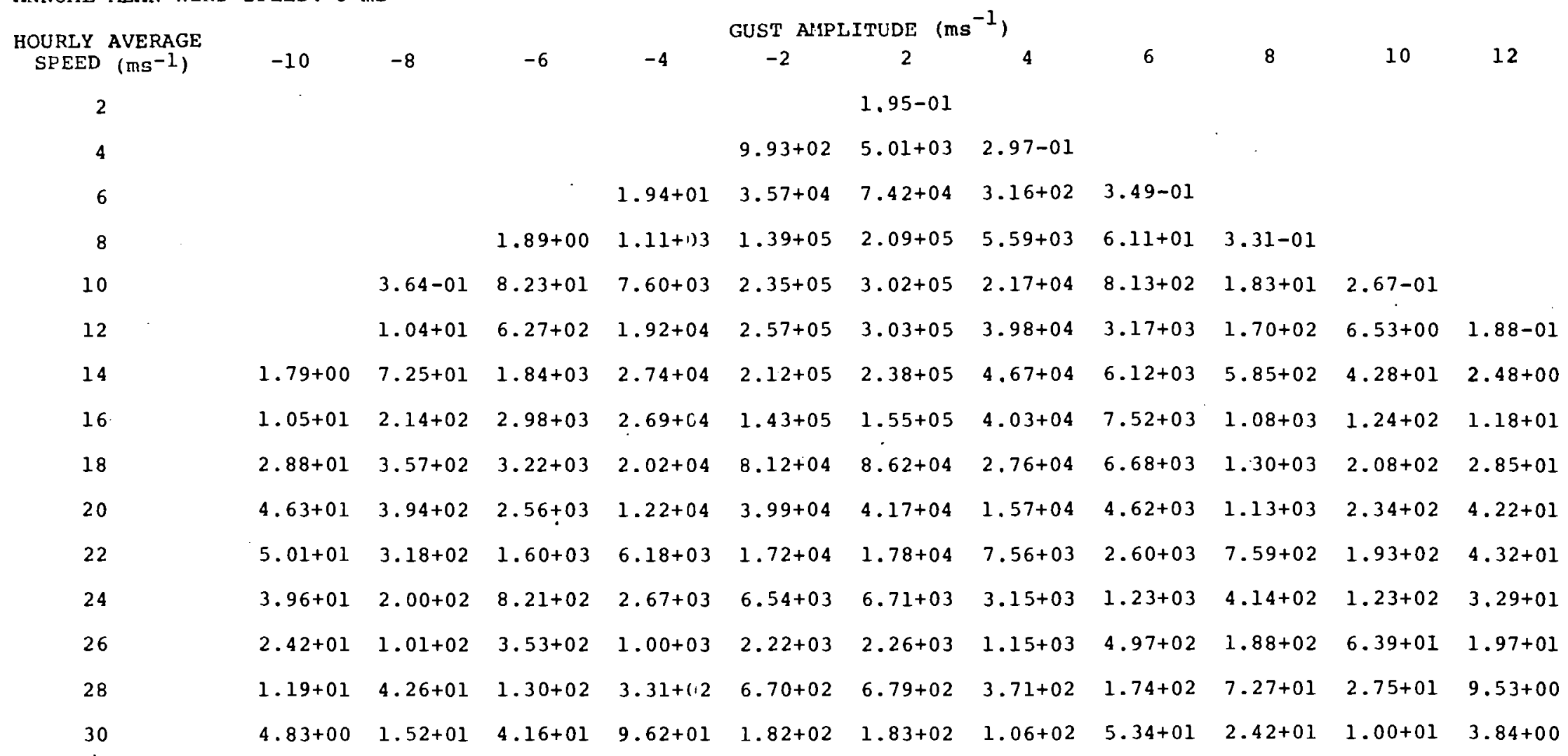


TABLE $\quad A_{-}-9$

TERRAIN : Flat/Gently Rolling ANNUAL MEAN WIND SPEED: $10 \mathrm{~ms}^{-1}$

HOURLY
SPEED
2
4
6
8
10
12
14
16
18
20
22
24
26
28
30

$\left(m s^{-1}\right)$

$-10$

4

\section{.}

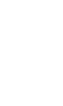

$-8$

$-6$

$-6 \quad-4$

$\underset{-2}{\text { GUST AMPLITUDE }}\left(\mathrm{ms}^{-1}\right)$

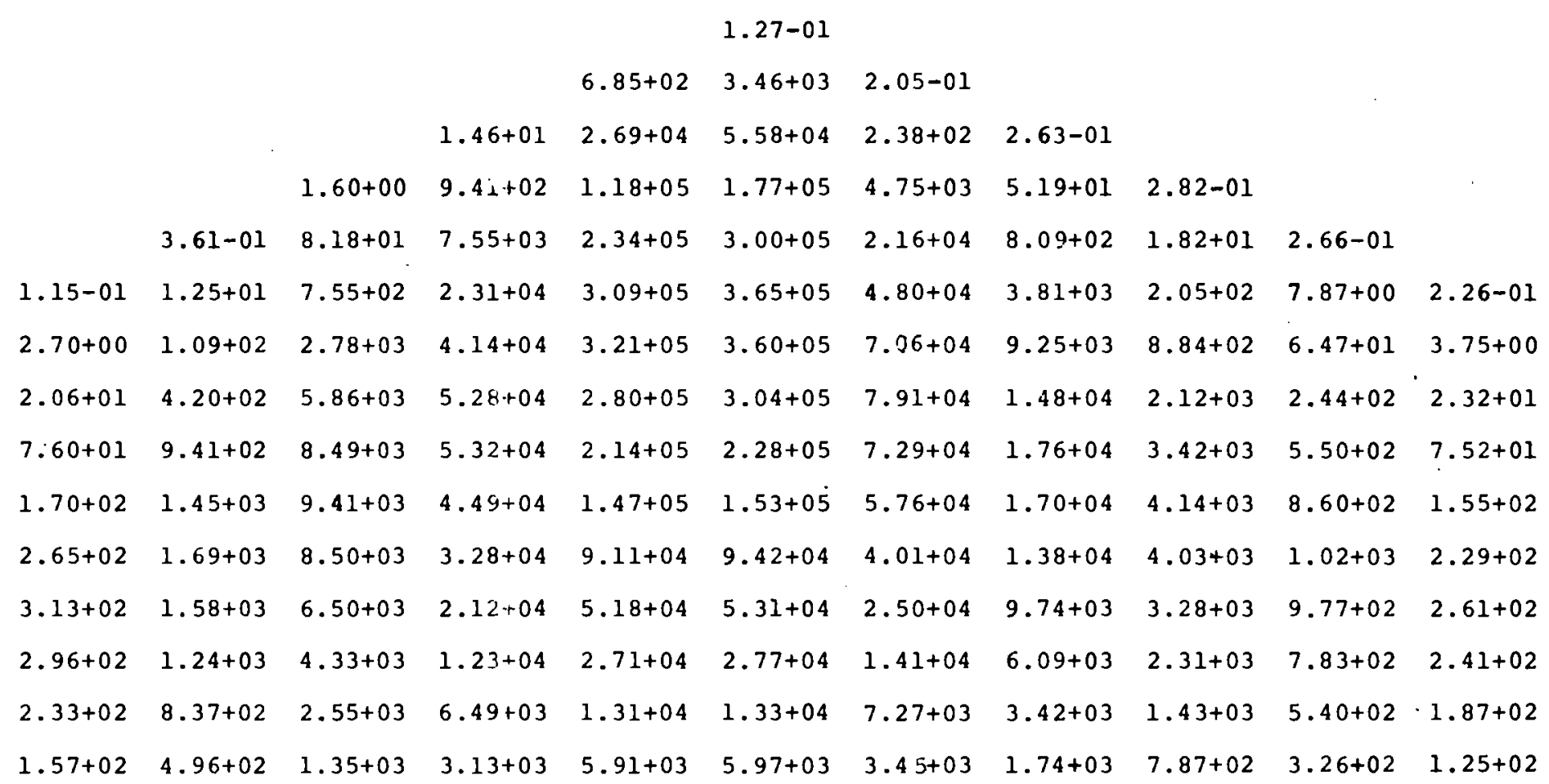

$1.27-01$ 
TABLE A-10

TERRAIN: Flat/Gently Rolling ANNUAL MEAN WIND SPEED: $12 \mathrm{~ms}^{-1}$

\begin{tabular}{|c|c|c|c|c|c|c|c|c|c|c|c|}
\hline $\begin{array}{l}\text { HOURLY AVERAGE } \\
\text { SPEED }\left(\mathrm{ms}^{-1}\right)\end{array}$ & -10 & -8 & -6 & -4 & $\begin{array}{l}\text { UST AMPLI } \\
-2\end{array}$ & ${ }_{2}^{\text {TUDE }}$ & 1 , & 6 & 8 & 10 & 12 \\
\hline 2 & & & & & & & & & & & \\
\hline 4 & & & & & $4.95+02$ & $2.50+03$ & $1.48-01$ & & & & \\
\hline 6 & & & & $1.11+01$ & $2.04+04$ & $4.23+04$ & $1.80+02$ & $1.99-01$ & & & \\
\hline 8 & & & $1.30+00$ & $7.63+02$ & $9.60+04$ & $1.44+05$ & $3.85+03$ & $4.21+01$ & $2.28-01$ & & \\
\hline 10 & & $3.19-01$ & $7.23+01$ & $6.67+03$ & $2.06+05$ & $2.65+05$ & $1.91+04$ & $7.14+02$ & $1.61+01$ & $2.35-01$ & \\
\hline 12 & $1.13-01$ & $1.23+01$ & $7.41+02$ & $2.27+04$ & $3.03+05$ & $3.58+05$ & $4.70+04$ & $3.74+03$ & $2.01+02$ & $7.72+00$ & $2.22-01$ \\
\hline 14 & $3.00+00$ & $1.21+02$ & $3.09+03$ & $4.59+04$ & $3.56+05$ & $3.99+05$ & $7.83+04$ & $1.03+04$ & $9.81+02$ & $7.18+01$ & $4.16+00$ \\
\hline 16 & $2.63+01$ & $5.37+02$ & $7.49+03$ & $6.76+04$ & $3.59+05$ & $3.89+05$ & $1.01+05$ & $1.89+04$ & $2.71+03$ & $3.13+02$ & $2.97+01$ \\
\hline 18 & $1.14+02$ & $1.42+03$ & 1. $28+04$ & $8.01+04$ & $3.22+05$ & $3.42+05$ & $1.10+05$ & $2.65+04$ & $5.14+03$ & $8.28+02$ & $1.13+02$ \\
\hline 20 & $3.07+02$ & $2.61+03$ & $1.70+04$ & $8.09+04$ & $2.64+05$ & $2.76+05$ & $1.04+05$ & $3.06+04$ & $7.46+03$ & $1.55+03$ & $2.80+02$ \\
\hline 22 & $5.84+02$ & $3.72+03$ & $1.87+04$ & $7.21+1) 4$ & $2.01+05$ & $2.07+05$ & $8.82+04$ & $3.04+04$ & $8.86+03$ & $2.25+03$ & $5.04+02$ \\
\hline 24 & $8.58+02$ & $4.33+03$ & $1.78+04$ & $5.80+04$ & $1.42+05$ & $1.46+05$ & $6.84+04$ & $2.67+04$ & $8.99+03$ & $2.68+03$ & $7.15+02$ \\
\hline 26 & $1.03+03$ & $4.31+03$ & $1.50+04$ & $4.27+04$ & $9.43+04$ & $9.61+04$ & $4.90+04$ & $2.12+04$ & $8.02+03$ & $2.72+03$ & $8.38+02$ \\
\hline 28 & $1.05+03$ & $3.76+03$ & $1.15+04$ & $2.91+04$ & $5.91+04$ & $5.99+04$ & $3.27+04$ & $1.54+04$ & $6.41+03$ & $2.42+03$ & $8.40+02$ \\
\hline 30 & $9.31+02$ & $2.94+03$ & $8.01+03$ & $1.85+04$ & $3.50+04$ & $3.53+04$ & $2.04+04$ & $1.03+04$ & $4.66+03$ & $1.93+03$ & $7.40+02$ \\
\hline
\end{tabular}


TABLE A-11

TERRAIN: Hilly

ANNUAL MEAN WIND SPEED: $4 \mathrm{~ms}^{-1}$

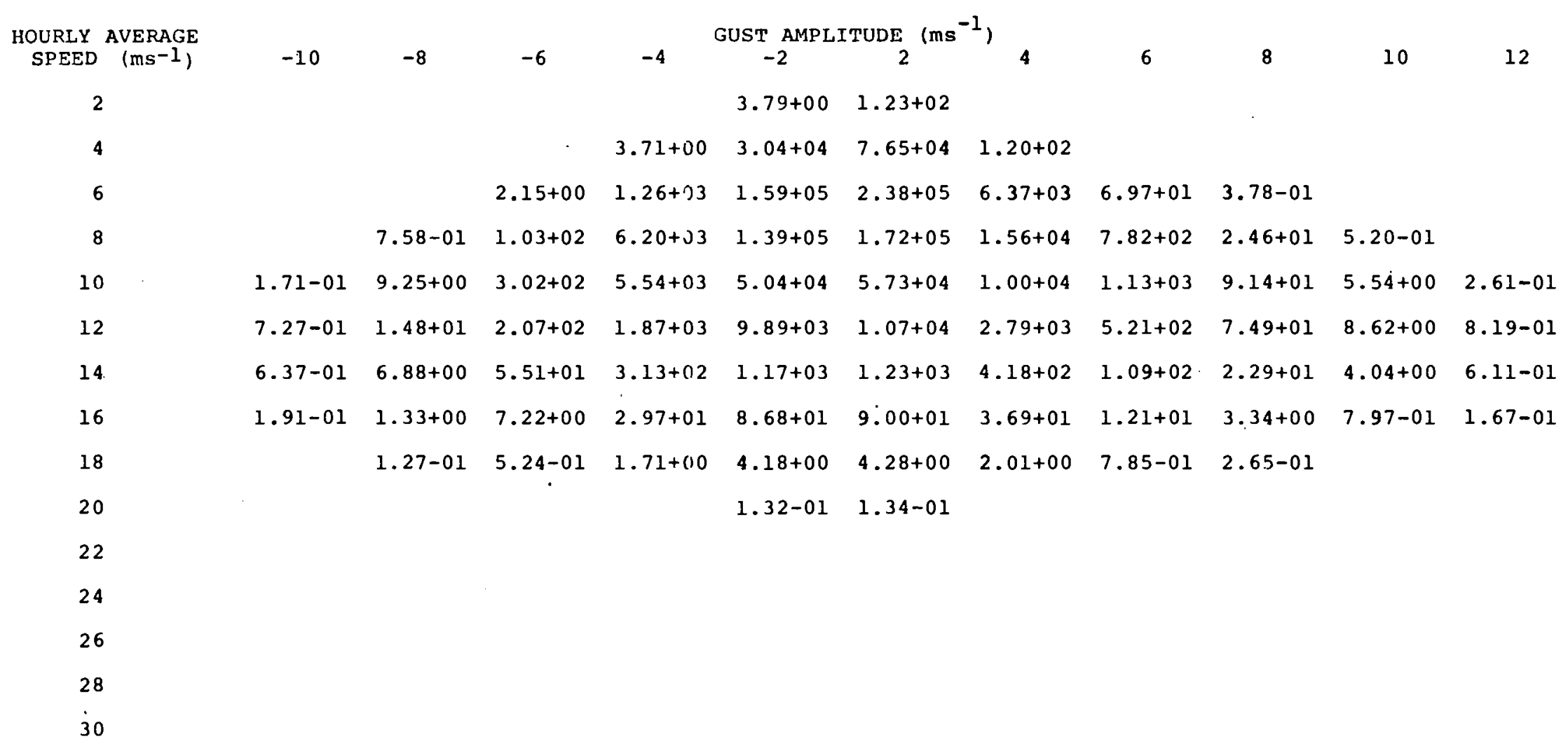


TERRAIN: Hilly

ANNUAL MEAN WIND SPEED: $6 \mathrm{~ms}^{-1}$

\begin{tabular}{|c|c|c|c|c|c|c|c|c|c|c|c|}
\hline $\begin{array}{l}\text { HOURLY AVERAGE } \\
\text { SPEED }\left(\mathrm{ms}^{-1}\right)\end{array}$ & -10 & -8 & -6 & -4 GUS & $\begin{array}{l}\text { T AMPLITL } \\
-2\end{array}$ & $\mathrm{DE} \underset{2}{\left(\mathrm{~ms}^{-1}\right)}$ & 4 & 6 & 8 & 10 & 12 \\
\hline 2 & & & & & $1.89+00$ & $6.12+01$ & & & & & \\
\hline 4 & & & & $2.57+00$ & $2.10+04$ & $5.29+04$ & $8.32+01$ & & & & \\
\hline 6 & & & $2.51+00$ & $1.47+03$ & $1.85+05$ & $2.77+05$ & $7.42+03$ & $8.11+01$ & $4.40-01$ & & \\
\hline 8 & & $1.83+00$ & $2.49+02$ & $1.50+04$ & $3.35+05$ & $4.16+05$ & $3.77+04$ & $1.89+03$ & $5.93+01$ & $1.26+00$ & \\
\hline 10 & $1.06+00$ & $5.70+01$ & $1.86+03$ & $3.42+04$ & $3.11+05$ & $3.54+05$ & $6.17+04$ & $6.98+03$ & $5.63+02$ & $3.42+01$ & $1.61+00$ \\
\hline 12 & $1.41+01$ & $2.88+02$ & $4.02+03$ & $3.63+104$ & $1.92+05$ & $2.09+05$ & $5.43+04$ & $1.01+04$ & $1.45+03$ & $1.68+02$ & $1.59+01$ \\
\hline 14 & $4.82+01$ & $5.21+02$ & $4.17+03$ & $2.36+04$ & $8.83+04$ & $9.32+04$ & $3.16+04$ & $8.22+03$ & $1.73+03$ & $3.06+02$ & $4.62+01$ \\
\hline 16 & $6.93+01$ & $4.82+02$ & $2.62+03$ & $1.08+04$ & $3.16+04$ & $3.27+04$ & $1.34+04$ & $4.40+03$ & $1.21+03$ & $2.90+02$ & $6.07+01$ \\
\hline 18 & $5.46+01$ & $2.75+02$ & $1.13+03$ & $3.69+03$ & $9.03+03$ & $9.26+03$ & $4.35+03$ & $1.70+03$ & $5.72+02$ & $1.70+02$ & $4.54+01$ \\
\hline 20 & $2.72+01$ & $1.08+02$ & $3.59+02$ & $9.80+.02$ & $2.10+03$ & $2.13+03$ & $1.11+03$ & $4.96+02$ & $1.94+02$ & $6.85+01$ & $2.20+01$ \\
\hline 22 & $9 \cdot 37+00$ & $3.08+01$ & $8.70+01$ & $2.07+02$ & $4.00+02$ & $4.04+02$ & $2.29+02$ & $1.13+02$ & $5.00+01$ & $2.01+01$ & $7.46+00$ \\
\hline 24 & $2.36+00$ & $6.67+00$ & $1.66+01$ & $3.54+01$ & $6.29+01$ & $6.34+01$ & $3.84+01$ & $2.06+01$ & $9.99+00$ & $4.47+00$ & $1.86+00$ \\
\hline 26 & $4.49-01$ & $1.13+00$ & $2.52+00$ & $4.93 i-1) 0$ & $8.21+00$ & $8.24+00$ & $5.27+00$ & $3.02+00$ & $1.59+00$ & $7.74-01$ & $3.55-01$ \\
\hline 28 & & $1.51-01$ & $3.10-01$ & $5.65-01$ & $8.90-01$ & $8.91-01$ & $5.96-01$ & $3.61-01$ & $2.02-01$ & $1.06-01$ & $\cdot$ \\
\hline
\end{tabular}


TABLE A-13

TERRAIN : Hilly

ANNUAL MEAN WIND SPEED: $8 \mathrm{~ms}^{-1}$

HOURLY
SPEED
2
4
6
8
10
12
14
16
18
20
22
24
26
28
30

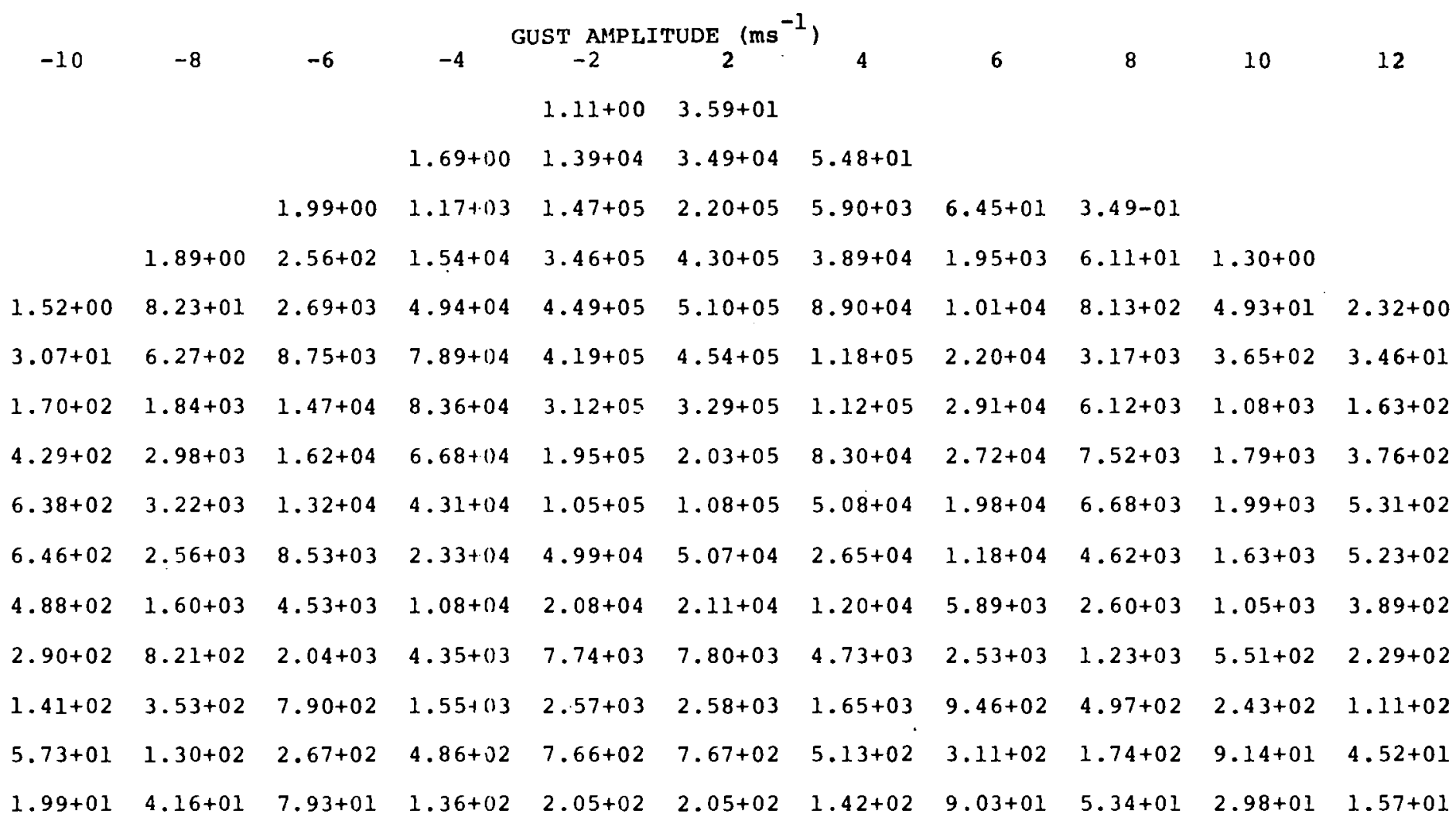


TERRAIN: Hilly

ANNUAL MEAN WIND SPEED: $10 \mathrm{~ms}^{-1}$

\begin{tabular}{|c|c|c|c|c|c|c|c|c|c|c|c|}
\hline $\begin{array}{l}\text { HOURLY AVERAGE } \\
\text { SPEED }\left(\mathrm{ms}^{-1}\right)\end{array}$ & -10 & -8 & -6 & -4 & $\begin{array}{l}\text { ST } \\
-2\end{array}$ & UDE ${ }_{2} \mathrm{~ms}^{-1}$ & 4 & 6 & 8 & 10 & 12 \\
\hline 2 & & & & & $7.24-01$ & $2.34+01$ & & & & & \\
\hline 4 & & & & $1.17+00$ & $9.55+03$ & $2.41+04$ & $3.78+01$ & & & & \\
\hline 6 & & & $1.50+00$ & $8.78+112$ & $1.11+05$ & $1.66+05$ & $4.43+03$ & $4.85+01$ & $2.63-01$ & & \\
\hline 8 & & $1.60+00$ & $2.18+02$ & $1.31+04$ & $2.94+05$ & $3.65+05$ & $3.31+04$ & $1.65+03$ & $5.19+01$ & $1.10+00$ & \\
\hline 10 & $1.51+00$ & $8.18+01$ & $2.67+03$ & $4.91+04$ & $4.46+05$ & $5.07+05$ & $8.85+04$ & $1.00+04$ & $8.09+02$ & $4.90+01$ & $2.31+00$ \\
\hline 12 & $3.70+01$ & $7.55+02$ & $1.05+04$ & $9.50+04$ & $5.04+05$ & $5.47+05$ & $1.42+05$ & $2.66+04$ & $3.81+03$ & $4.39+02$ & $4.17+01$ \\
\hline 14 & $2.57+02$ & $2.78+03$ & $2.23+04$ & $1.26+05$ & $4.71+05$ & $4.98+05$ & $1.69+05$ & $4.39+04$ & $9.25+03$ & $1.63+03$ & $2.47+02$ \\
\hline 16 & $8.42+02$ & $5.86+03$ & $3.19+04$ & $1.31+05$ & $3.83+05$ & $3.98+05$ & $1.63+05$ & $5.35+04$ & $1.48+04$ & $3 \cdot 52+03$ & $7.38+02$ \\
\hline 18 & $1.68+03$ & $8.49+03$ & $3.49+04$ & $1.14+05$ & $2.78+05$ & $2.85+05$ & $1.34+05$ & $5.23+04$ & $1.76+04$ & $5.25+03$ & $1.40+03$ \\
\hline 20 & $2.38+03$ & $9.41+03$ & $3.14+04$ & $8.56+04$ & $1.83+05$ & $1.86+05$ & $9.74+04$ & $4.33+04$ & $1.70+04$ & $5.99+03$ & $1.92+03$ \\
\hline 22 & $2.59+03$ & $8.50+03$ & $2.40+04$ & $5.72+04$ & $1.10+05$ & $1.12+05$ & $6.34+04$ & $3.12+04$ & $1.38+04$ & $5.56+03$ & $2.06+03$ \\
\hline 24 & $2.30+03$ & $6.50+03$ & $1.61+04$ & $3.45+04$ & $6.13+04$ & $6.18+04$ & $3.74+04$ & $2.00+04$ & $9.74+03$ & $4 \cdot 36+03$ & $1.82+03$ \\
\hline 26 & $1.72+03$ & $4.33+03$ & $9.68+03$ & $1.89+04$ & $3.15+04$ & $3.16+04$ & $2.02+04$ & $1.16+04$ & $6.09+03$ & $2.97+03$ & $1 \cdot 36+03$ \\
\hline 28 & $1.12+03$ & $2.55+03$ & $5.24+03$ & $9.53+03$ & $1.50+04$ & $1.50+04$ & $1.01+04$ & $6.10+03$ & $3.42+03$ & $1.79+03$ & $8.88+02$ \\
\hline 30 & $6.46+02$ & $1.35+03$ & $2.58+03$ & $4.42+103$ & $6.66+03$ & $6.66+03$ & $4.62+03$ & $2.94+03$ & $1.74+03$ & $9.68+02$ & $5.12+02$ \\
\hline
\end{tabular}


TABLE A-15

TERRAIN : Hilly

ANNUAL MEAN WIND SPEED: $12 \mathrm{~ms}^{-1}$

\begin{tabular}{|c|c|c|c|c|c|c|c|c|c|c|c|}
\hline $\begin{array}{l}\text { HOURLY AVERAGE } \\
\text { SPEED }\left(\mathrm{ms}^{-1}\right)\end{array}$ & -10 & -8 & -6 & -4 & $\begin{array}{c}\text { UST AMPL } \\
-2\end{array}$ & $\operatorname{TUDE}_{2}(\mathrm{~ms}$ & 1) & 6 & 8 & 10 & 12 \\
\hline 2 & & & & & $5.08-01$ & $1.65+01$ & & & & & \\
\hline 4 & & & & $8.44-01$ & $6.90+03$ & $1.74+04$ & $2.73+01$ & & & & \\
\hline 6 & & & $1.14+00$ & $6.66+c 2$ & $8.38+04$ & $1.26+05$ & $3.36+03$ & $3.68+01$ & $1.99-01$ & & \\
\hline 8 & & $1.30+00$ & $1.77+02$ & $1.06+c 4$ & $2.38+05$ & $2.96+05$ & $2.68+04$ & $1.34+03$ & $4.21+01$ & $8.92-01$ & \\
\hline 10 & $1.34+00$ & $7.23+01$ & $2.36+03$ & $4.33+04$ & $3.94+05$ & $4.48+05$ & $7.82+04$ & $8.85+03$ & $7.14+02$ & $4.33+01$ & $2.04+00$ \\
\hline 12 & $3.63+01$ & $7.41+02$ & $1.03+04$ & $9.32+04$ & $4.94+05$ & $5.36+05$ & $1.40+05$ & $2.60+04$ & $3.74+03$ & $4.31+02$ & $4.09+01$ \\
\hline 14 & $2.86+02$ & $3.09+03$ & $2.47+04$ & $1.40+05$ & $5.23+05$ & $5.52+05$ & $1.87+05$ & $4.87+04$ & $1.03+04$ & $1.81+03$ & $2.74+02$ \\
\hline 16 & $1.08+03$ & $7.49+03$ & $4.08+04$ & $1.68+05$ & $4.91+05$ & $5.09+05$ & $2.08+05$ & $6.84+04$ & $1.89+04$ & $4.50+03$ & $9.45+02$ \\
\hline 18 & $2.53+03$ & $1.28+04$ & $5.26+04$ & $1.71+05$ & $4.19+05$ & $4.29+05$ & $2.02+05$ & $7.87+04$ & $2.65+04$ & $7.90+03$ & $2.11+03$ \\
\hline 20 & $4.28+03$ & $1.70+04$ & $5.65+04$ & $1.54+05$ & $3.30+05$ & $3.36+05$ & $1.76+05$ & $7.81+04$ & $3.06+04$ & $1.08+04$ & $3.47+03$ \\
\hline 22 & $5.70+03$ & $1.87+04$ & $5.29+04$ & $1.26+05$ & $2.43+05$ & $2.46+05$ & $1.39+05$ & $6.88+04$ & $3.04+04$ & $1.22+04$ & $4.54+03$ \\
\hline 24 & $6.29+03$ & $1.78+04$ & $4.42+04$ & $9.45+04$ & $1.68+05$ & $1.69+05$ & $1.03+05$ & $5.49+04$ & $2.67+04$ & $1.19+04$ & $4.98+03$ \\
\hline 26 & $5.99+03$ & $1.50+04$ & $3 \cdot 36+04$ & $6.58+? 4$ & $1.09+05$ & $1.10+05$ & $7.03+04$ & $4.03+04$ & $2.12+04$ & $1.03+04$ & $4.73+03$ \\
\hline 28 & $5.05+03$ & $1.15+04$ & $2.35+04$ & $4.28+04$ & $6.75+04$ & $6.76+04$ & $4.52+04$ & $2.74+04$ & $1.54+04$ & $8.05+03$ & $3.99+03$ \\
\hline 30 & $3.83+03$ & $8.01+03$ & $1.53+04$ & $2.62+04$ & $3.94+04$ & $3.94+04$ & $2.74+04$ & $1.74+04$ & $1.03+04$ & $5.73+03$ & $3.03+03$ \\
\hline
\end{tabular}


TABLE A-16

TERRAIN: Low Mountains

ANNUAL MEAN WIND SPEED: $4 \mathrm{~ms}^{-1}$

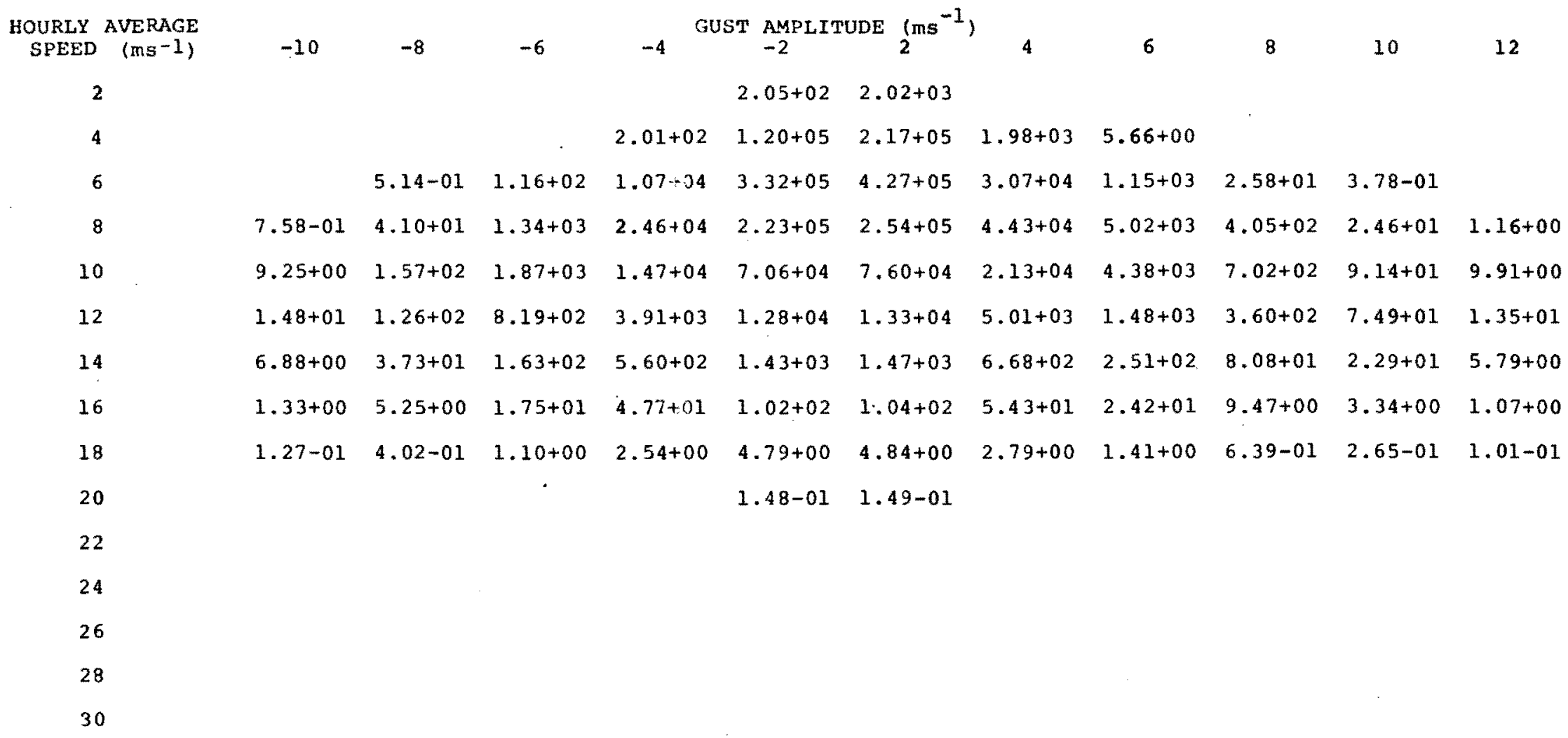


TABLE A-17

TERRAIN : Low Mountains

ANNUAL MEAN WIND SPEED: $6 \mathrm{~ms}^{-1}$

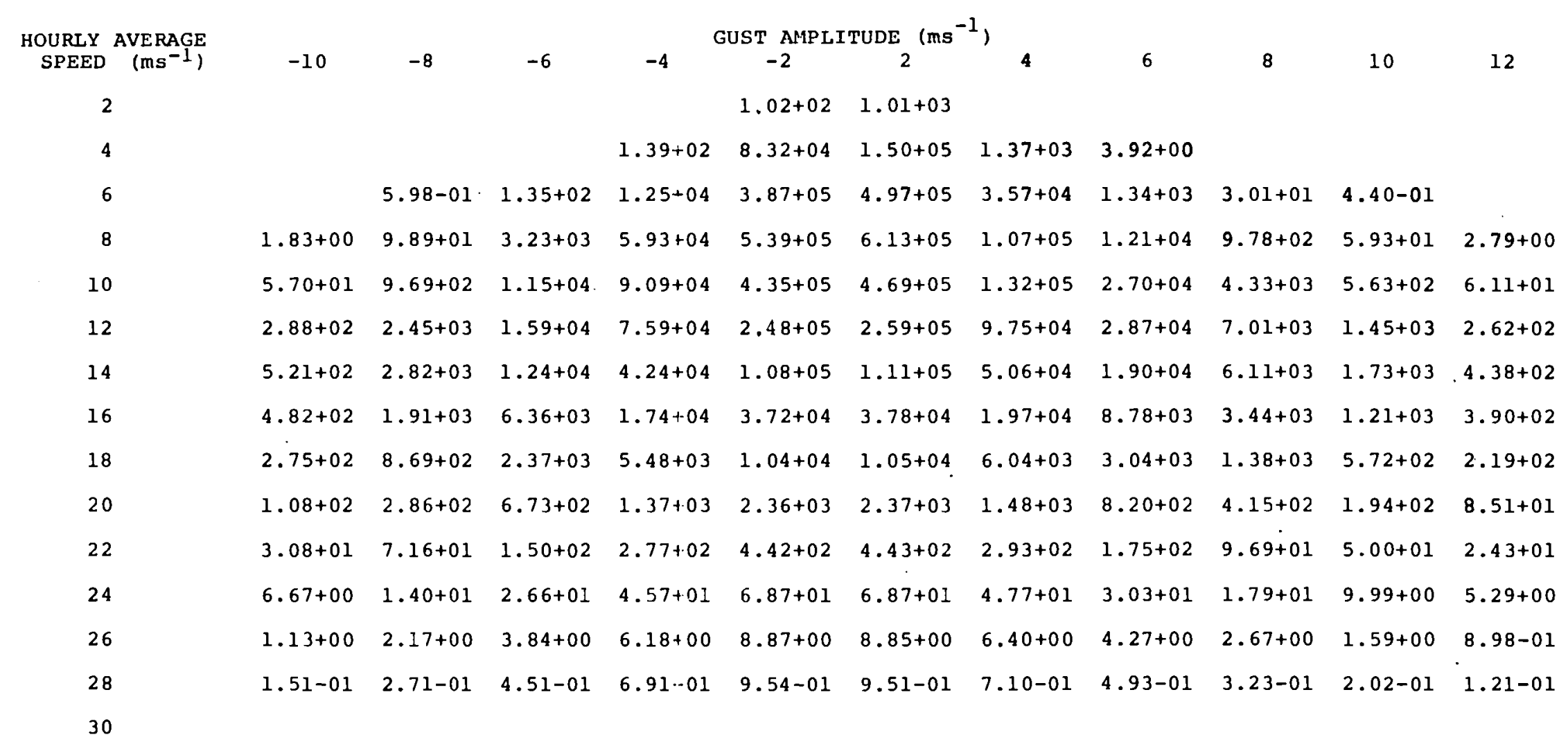


TABLE A-18

TERRAIN: LOW Mountains

ANNUAL MEAN WIND SPEED: $8 \mathrm{~ms}^{-1}$

\begin{tabular}{|c|c|c|c|c|c|c|c|c|c|c|c|}
\hline $\begin{array}{l}\text { HOURLY AVERAGE } \\
\text { SPEED }\left(\mathrm{ms}^{-1}\right)\end{array}$ & -10 & -8 & -6 & -4 & $\begin{array}{l}\text { UST AMPLI } \\
-2\end{array}$ & $\mathrm{PUDE}_{2}(\mathrm{~ms}$ & 4 & 6 & 8 & 10 & 12 \\
\hline 2 & & & & & $6.00+01$ & $5.92+02$ & & & & & \\
\hline 4 & & & & $9.15+01$ & $5.49+04$ & $9.90+04$ & $9.05+02$ & $2.59+00$ & & & \\
\hline 6 & & $4.75-01$ & $1.08+02$ & $9.94+03$ & $3.08+05$ & $3.95+05$ & $2.84+04$ & $1.06+03$ & $2.39+01$ & $3.49-01$ & \\
\hline 8 & $1.89+00$ & $1.02+02$ & $3.33+03$ & $6.12+04$ & $5.56+05$ & $6.33+05$ & $1.10+05$ & $1.25+04$ & $1.01+03$ & $6.11+01$ & $2.88+00$ \\
\hline 10 & $8.23+01$ & $1.40+03$ & $1.66+04$ & $1.31+05$ & $6.29+05$ & $6.77+05$ & $1.90+05$ & $3.90+04$ & $6.25+03$ & $8.13+02$ & $8.82+01$ \\
\hline 12 & $6.27+02$ & $5.34+03$ & $3.47+04$ & $1.65+05$ & $5.40+05$ & $5.65+05$ & $2.12+05$ & $6.25+04$ & $1.52+04$ & $3.17+03$ & $5.71+02$ \\
\hline 14 & $1.84+03$ & $9.98+03$ & $4.37+04$ & $1.50+05$ & $3.82+05$ & $3.92+05$ & $1.79+05$ & $6.71+04$ & $2.16+04$ & $6.12+03$ & $1.55+03$ \\
\hline 16 & $2.98+03$ & $1.18+04$ & $3.94+04$ & $1.07+05$ & $2.30+05$ & $2.34+05$ & $1.22+05$ & $5.44+04$ & $2.13+04$ & $7.52+03$ & $2.41+03$ \\
\hline 18 & $3.22+03$ & $1.02+04$ & $2.77+04$ & $6.41+04$ & $1.21+05$ & $1.22+05$ & $7.06+04$ & $3.56+04$ & $1.61+04$ & $6.68+03$ & $2.56+03$ \\
\hline 20 & $2.56+03$ & $6.81+03$ & $1.60+04$ & $3.26+04$ & $5.60+04$ & $5.63+04$ & $3.51+04$ & $1.95+04$ & $9.86+03$ & $4.62+03$ & $2.02+03$ \\
\hline 22 & $1.60+03$ & $3.73+03$ & $7.80+03$ & $1.44+114$ & $2.30+04$ & $2.31+04$ & $1.53+04$ & $9.14+03$ & $5.05+03$ & $2.60+03$ & $1.27+03$ \\
\hline 24 & $8.21+02$ & $1.72+03$ & $3.28+03$ & $5.62+03$ & $8.46+03$ & $8.46+03$ & $5.87+03$ & $3.73+03$ & $2.21+03$ & $1.23+03$ & $6.51+02$ \\
\hline 26 & $3.53+02$ & $6.79+02$ & $1.20+03$ & $1.94+03$ & $2.78+03$ & $2.78+03$ & $2.01+03$ & $1.34+03$ & $8.37+02$ & $4.97+02$ & $2.82+02$ \\
\hline 28 & $1.30+02$ & $2.33+02$ & $3.88+02$ & $5.94+02$ & $8.21+02$ & $8.18+02$ & $6.11+02$ & $4.24+02$ & $2.78+02$ & $1.74+02$ & $1.04+02$ \\
\hline 30 & $4.16+01$ & $7.03+01$ & $1.11+02$ & $1.63+102$ & $2.18+02$ & $2.17+02$ & $1.67+02$ & $1.20+02$ & $8.17+01$ & $5.34+01$ & $3.36+01$ \\
\hline
\end{tabular}


TABLE A-19

TERRAIN: LOW Mountains ANNUAL MEAN WIND SPEED: $10 \mathrm{~ms}^{-1}$

\begin{tabular}{|c|c|c|c|c|c|c|c|c|c|c|c|}
\hline $\begin{array}{l}\text { HOURLY AVERAGE } \\
\text { SPEED (ms }\end{array}$ & -10 & -8 & -6 & -4 & $\begin{array}{l}\text { UST AMPL } \\
-2\end{array}$ & $\mathrm{PUDE}_{2}(\mathrm{~ms}$ & 4 & 6 & 8 & 10 & 12 \\
\hline 2 & & & & & $3.91+01$ & $3.87+02$ & & & & & \\
\hline 4 & & & & $6.31+01$ & $3.78+04$ & $6.82+04$ & $6.23+02$ & $1.78+00$ & & & \\
\hline 6 & & $3.58-01$ & $8.09+01$ & $7.4 \%+03$ & $2.31+05$ & $2.97+05$ & $2.13+04$ & $8.00+02$ & $1.80+01$ & $2.63-01$ & \\
\hline 8 & $1.60+00$ & $8.67+01$ & $2.83+03$ & $5.20+04$ & $4.73+05$ & $5.38+05$ & $9.38+04$ & $1.06+04$ & $8.57+02$ & $5.19+01$ & $2.45+00$ \\
\hline 10 & $8.18+01$ & $1.39+03$ & $1.65+04$ & $1.30+05$ & $6.25+05$ & $6.73+05$ & $1.89+05$ & $3.87+04$ & $6.21+03$ & $8.09+02$ & $8.77+01$ \\
\hline 12 & $7.55+02$ & $6.43+03$ & $4.17+04$ & $1.99+05$ & $6.51+05$ & $6.80+05$ & $2.55+05$ & $7.53+04$ & $1.84+04$ & $3.81+03$ & $6.88+02$ \\
\hline 14 & $2.78+03$ & $1.51+04$ & $6.60+04$ & $2.26+05$ & $5.77+05$ & $5.93+05$ & $2.70+05$ & $1.01+05$ & $3.26+04$ & $9.25+03$ & $2.34+03$ \\
\hline 16 & $5.86+03$ & $2.32+04$ & $7.73+04$ & $2.11+05$ & $4.52+05$ & $4.59+05$ & $2.40+05$ & $1.07+05$ & $4.19+04$ & $1.48+04$ & $4.74+03$ \\
\hline 18 & $8.49+03$ & $2.68+04$ & $7.31+04$ & $1.69+05$ & $3.19+05$ & $3.22+05$ & $1.86+05$ & $9.39+04$ & $4.26+04$ & $1.76+04$ & $6.75+03$ \\
\hline 20 & $9.41+03$ & $2.50+04$ & $5.88+04$ & $1.20+05$ & $2.06+05$ & $2.07+05$ & $1.29+05$ & $7.16+04$ & $3.62+04$ & $1.70+04$ & $7.43+03$ \\
\hline 22 & $8.50+03$ & $1.98+04$ & $4.14+04$ & $7.66+04$ & $1.22+05$ & $1.22+05$ & $8.11+04$ & $4.85+04$ & $2.68+04$ & $1.38+04$ & $6.71+03$ \\
\hline 24 & $6.50+03$ & $1.36+04$ & $2.60+04$ & $4.45+04$ & $6.70+04$ & $6.70+04$ & $4.65+04$ & $2.95+04$ & $1.75+04$ & $9.74+03$ & $5.15+03$ \\
\hline 26 & $4.33+03$ & $8.32+03$ & $1.47+04$ & $2.37+04$ & $3.41+04$ & $3.40+04$ & $2.46+04$ & $1.64+04$ & $1.03+04$ & $6.09+03$ & $3.45+03$ \\
\hline 28 & $2.55+03$ & $4.58+03$ & $7.62+03$ & $1.17+04$ & $1.61+04$ & $1.60+04$ & $1.20+04$ & $8.32+03$ & $5.46+03$ & $3.42+03$ & $2.05+03$ \\
\hline 30 & $1.35+03$ & $2.29+03$ & $3.62+03$ & $5.30+03$ & $7.09+03$ & $7.06+03$ & $5.42+03$ & $3.89+03$ & $2.66+03$ & $1.74+03$ & $1.09+03$ \\
\hline
\end{tabular}


TABLE $A-20$

TERRAIN: LOW Mountains ANNUAL MEAN WIND SPEED: $12 \mathrm{~ms}^{-1}$

HOURLY A
SPEED
2
4
6
8
10
12
14
16
18
20
22
24
26
28
$30^{\circ}$

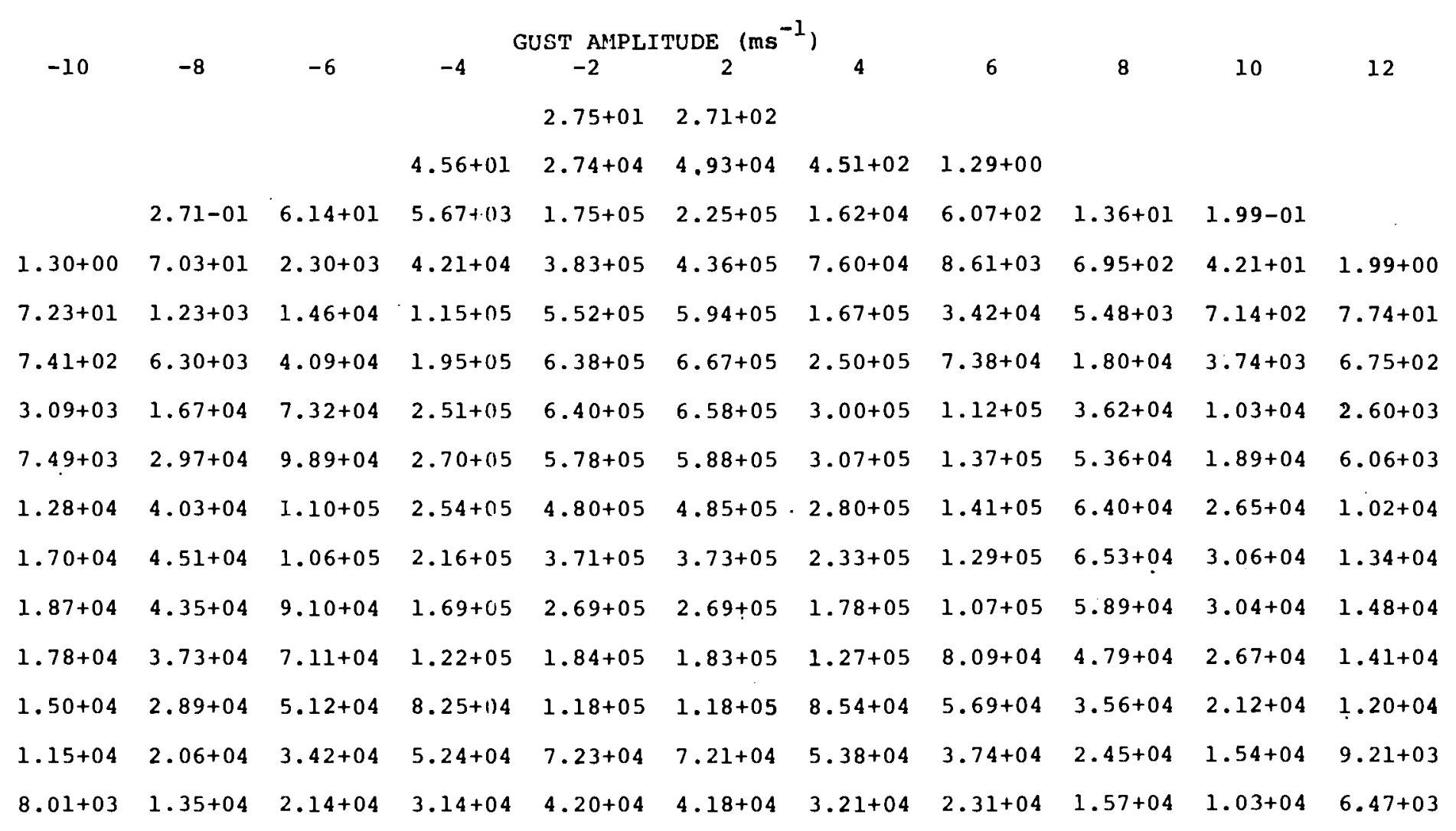


TABLE A-2 1

TERRAIN: High Mountains

ANNUAL MEAN WIND SPEED: $4 \mathrm{~ms}^{-1}$

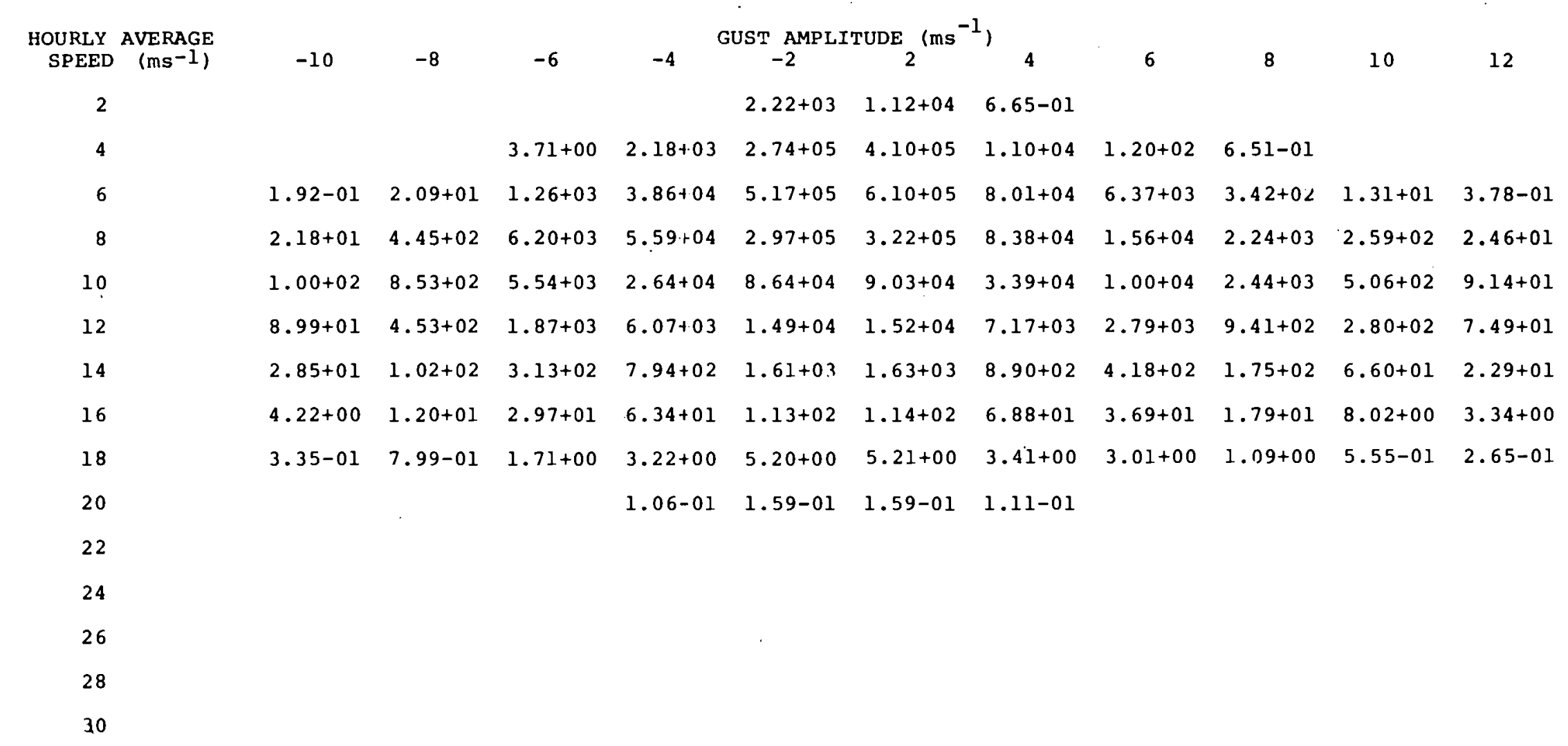




\section{TABLE A-22}

TERRAIN: High Mountains ANNUAL MEAN WIND SPEED: $6 \mathrm{~ms}^{-1}$

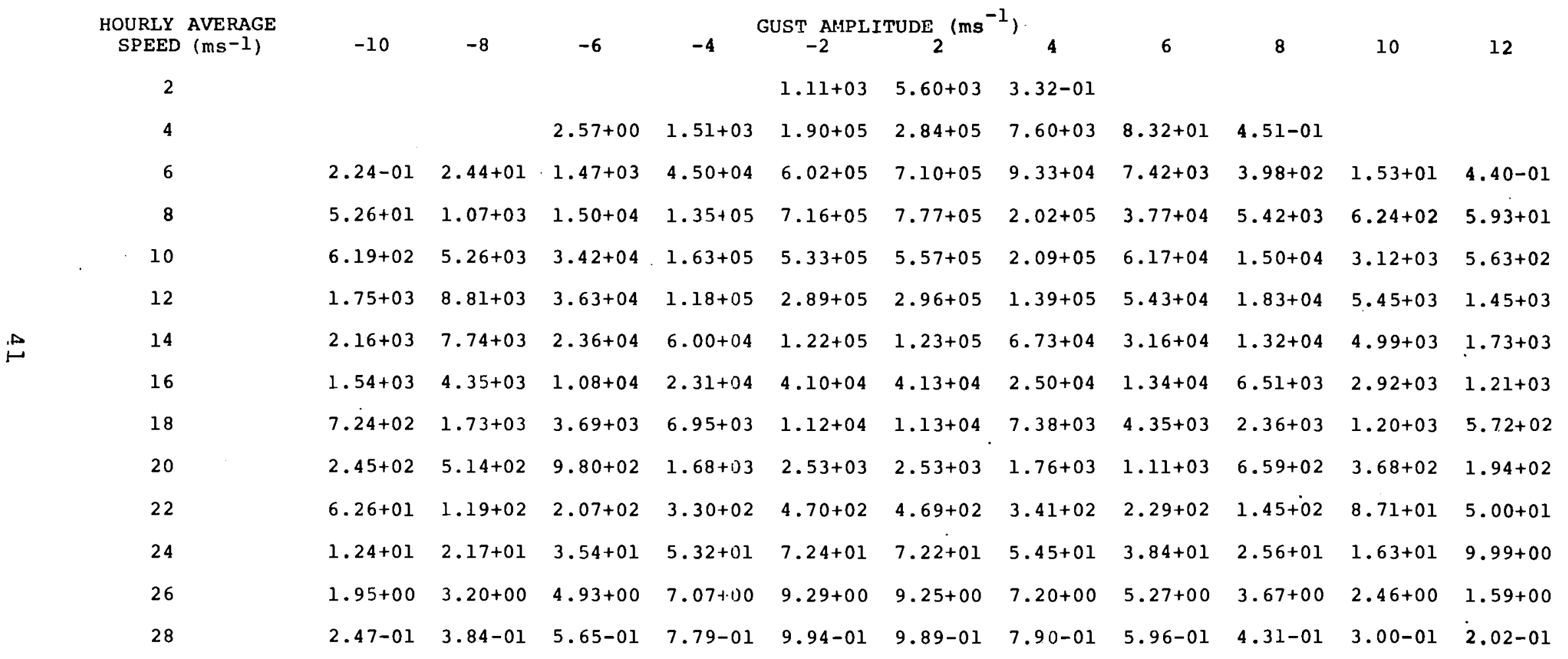


TABLE A-23

TERRAIN: High Mountains

ANNUAL MEAN WIND SPEED: $8 \mathrm{~ms}^{-1}$

\begin{tabular}{|c|c|c|c|c|c|c|c|c|c|c|c|}
\hline $\begin{array}{l}\text { HOURLY AVERAGE } \\
\text { SPEED }\left(\mathrm{ms}^{-1}\right)\end{array}$ & -10 & -8 & -6 & -4 & $\begin{array}{l}\text { IST AMPLIT } \\
-2\end{array}$ & UDE ${ }_{2}\left(\mathrm{~ms}^{-1}\right.$ & 4 & 6 & 8 & 10 & 12 \\
\hline 2 & & & & & $6.51+02$ & $3.28+03$ & $1.95-01$ & & & & \\
\hline 4 & & & $1.69+00$ & $9.93+02$ & $1.25+05$ & $1.87+05$ & $5.01+03$ & $5.48+01$ & $2.97-01$ & & \\
\hline 6 & $1.78-01$ & $1.94+01$ & $1.17+03$ & $3.57+04$ & $4.78+05$ & $5.64+05$ & $7.42+04$ & $5.90+03$ & $3.16+02$ & $1.22+01$ & $3.49-01$ \\
\hline 8 & $5.43+01$ & $1.11+03$ & $1.54+04$ & $1.39+0.5$ & $7.39+05$ & $8.02+05$ & $2.09+05$ & $3.89+04$ & $5.59+03$ & $6.44+02$ & $6.11+01$ \\
\hline 10 & $8.93+02$ & $7.60+03$ & $4.94+04$ & $2.35+05$ & $7.69+05$ & $8.04+05$ & $3.02+05$ & $8.90+04$ & $2.17+04$ & $4.51+03$ & $8.13+02$ \\
\hline 12 & $3.80+03$ & $1.92+04$ & $7.89+04$ & $2.57+05$ & $6.29+05$ & $6.45+05$ & $3.03+05$ & $1.18+05$ & $3.98+04$ & $1.19+04$ & $3.17+03$ \\
\hline 14 & $7.64+03$ & $2.74+04$ & $8.36+04$ & $2.12+05$ & $4.30+05$ & $4.36+05$ & $2.38+05$ & $1.12+05$ & $4.67+04$ & $1.77+04$ & $6.12+03$ \\
\hline 16 & $9.51+03$ & $2.69+04$ & $6.68+04$ & $1.43+05$ & $2.54+05$ & $2.56+05$ & $1.55+05$ & $8.30+04$ & $4.03+04$ & $1.81+04$ & $7.52+03$ \\
\hline 18 & $8.46+03$ & $2.02+04$ & $4.31+04$ & $8.12+04$ & $1.31+05$ & $1.32+05$ & 8. $62+04$ & $5.08+04$ & $2.76+04$ & $1.40+04$ & $6.68+03$ \\
\hline 20 & $5.83+03$ & $1.22+04$ & $2.33+04$ & $3.99+04$ & $6.01+04$ & $6.00+04$ & $4.17+04$ & $2.65+04$ & $1.57+04$ & $8.73+03$ & $4.62+03$ \\
\hline 22 & $3.26+03$ & $6.18+03$ & $1.08+04$ & $1.72+04$ & $2.45+04$ & $2.44+04$ & $1.78+04$ & $1.20+04$ & $7.56+03$ & $4.54+03$ & $2.60+03$ \\
\hline 24 & $1.53+03$ & $2.67+03$ & $4.35+03$ & $6.54+03$ & $8.91+03$ & $8.88+03$ & $6.71+03$ & $4.73+03$ & $3.15+03$ & $2.01+03$ & $1.23+03$ \\
\hline 26 & $6.13+02$ & $1.00+03$ & $1.55+03$ & $2.22+03$ & $2.91+03$ & $2.90+03$ & $2.26+03$ & $1.65+03$ & $1.15+03$ & $7.70+02$ & $4.97+02$ \\
\hline 28 & $2.13+02$ & $3.31+02$ & $4.86+02$ & $6.70+02$ & $8.55+02$ & $8.51+02$ & $6.79+02$ & $5.13+02$ & $3.71+02$ & $2.58+02$ & $1.74+02$ \\
\hline 30 & $6.47+01$ & $9.62+01$ & $1.36+02$ & $1.82+02$ & $2.26+02$ & $2.25+02$ & $1.83+02$ & $1.42+02$ & $1.06+02$ & $7.63+01$ & $5.34+01$ \\
\hline
\end{tabular}


TABLE A-24

IERRAIN: High Mountains

ANNUAL MEAN WIND SPEED: $10 \mathrm{~ms}^{-1}$

\begin{tabular}{|c|c|c|c|c|c|c|c|c|c|c|c|}
\hline $\begin{array}{l}\text { HOURLY AVERAGE } \\
\text { SPEED }\left(\mathrm{ms}^{-1}\right)\end{array}$ & -10 & -8 & -6 & -4 & $\begin{array}{l}\text { ST AMPLIT } \\
-2\end{array}$ & UDE ${ }_{2} \mathrm{~ms}^{-1}$ & 4 & 6 & 8 & 10 & 12 \\
\hline 2 & & & & & $4.25+02$ & $2.14+03$ & $1.27-01$ & & & & \\
\hline 4 & & & $1.17+00$ & $6.85+02$ & $8.61+04$ & $1.29+05$ & $3.46+03$ & $3.78+01$ & $2.05-01$ & & \\
\hline 6 & $1.34-01$ & $1.46+01$ & $8.78+02$ & $2.69+04$ & $3.60+05$ & $4.24+05$ & $5.58+04$ & $4.43+03$ & $2.38+02$ & $9.15+00$ & $2.63-01$ \\
\hline 8 & $4.61+01$ & $9.41+02$ & $1.31+04$ & $1.13+05$ & $6.28+05$ & $6.82+05$ & $1.77+05$ & $3.31+04$ & $4.75+03$ & $5.47+02$ & $5.19+01$ \\
\hline 10 & $8.88+02$ & $7.55+03$ & $4.91+04$ & $2.34+05$ & $7.64+05$ & $7.99+05$ & $3.00+05$ & $8.85+04$ & $2.16+04$ & $4: 48+03$ & $8.09+02$ \\
\hline 12 & $4.58+03$ & $2.31+04$ & $9.50+04$ & $3.09+05$ & $7.58+05$ & $7.77+05$ & $3.65+05$ & $1.42+05$ & $4.80+04$ & $1.43+04$ & $3.81+03$ \\
\hline 14 & $1.15+04$ & $4.14+04$ & $1.26+05$ & $3.2 \mathrm{~J}+05$ & $6.50+05$ & $6.59+05$ & $3.60+05$ & $1.69+05$ & $7.06+04$ & $2.67+04$ & $9.25+03$ \\
\hline 16 & $1.87+04$ & $5.28+04$ & $1.31+05$ & $2.80+05$ & $4.98+05$ & $\cdot 5.02+05$ & $3.04+05$ & $1.63+05$ & $7.91+04$ & $3.54+04$ & $1.48+04$ \\
\hline 18 & $2.23+04$ & $5.32+04$ & $1.14+05$ & $2.14+05$ & $3.46+05$ & $3.47+05$ & $2.28+05$ & $1.34+05$ & $7.29+04$ & $3.70+04$ & $1.76+04$ \\
\hline 20 & $2.14+04$ & $4.49+04$ & $8.56+04$ & $1.4 i+05$ & $2.21+05$ & $2.21+05$ & $1.53+05$ & $9.74+04$ & $5.76+04$ & $3.21+04$ & $1.70+v 4$ \\
\hline 22 & $1.73+04$ & 3. $28+04$ & $5.72+04$ & $9.11+04$ & $1.30+05$ & $1.29+05$ & $9.42+C 4$ & $6.34+04$ & $4.01+04$ & $2.41+04$ & 1. $38+04$ \\
\hline 24 & $1.21+04$ & $2.12+04$ & $3.45+04$ & $5.18+04$ & $7.06+04$ & $7.03+04$ & $5.31+04$ & $3.74+04$ & $2.50+04$ & $1.59+04$ & $9.74+03$ \\
\hline 26 & $7.50+03$ & $1.23+04$ & $1.89+04$ & $2.7 x+04$ & $3.57+04$ & $3.55+04$ & $2.77+04$ & $2.02+04$ & $1.41+04$ & $9.43+03$ & $6.09+03$ \\
\hline 28 & $4.17+03$ & $6.49+03$ & $9.53+03$ & $1.31+04$ & $1.68+04$ & $1.67+04$ & $1.33+04$ & $1.01+04$ & $7.27+03$ & $5.07+03$ & $3.42+03$ \\
\hline 30 & $2.10+03$ & $3.13+03$ & $4.42+03$ & $5.91+03$ & $7 \cdot 36+03$ & $7.32+03$ & $5.97+03$ & $4.62+03$ & $3.45+03$ & $2.48+03$ & $1.74+03$ \\
\hline
\end{tabular}


TERRAIN: High Mountains

ANNUAL MEAN WIND SPEED: $12 \mathrm{~ms}^{-1}$

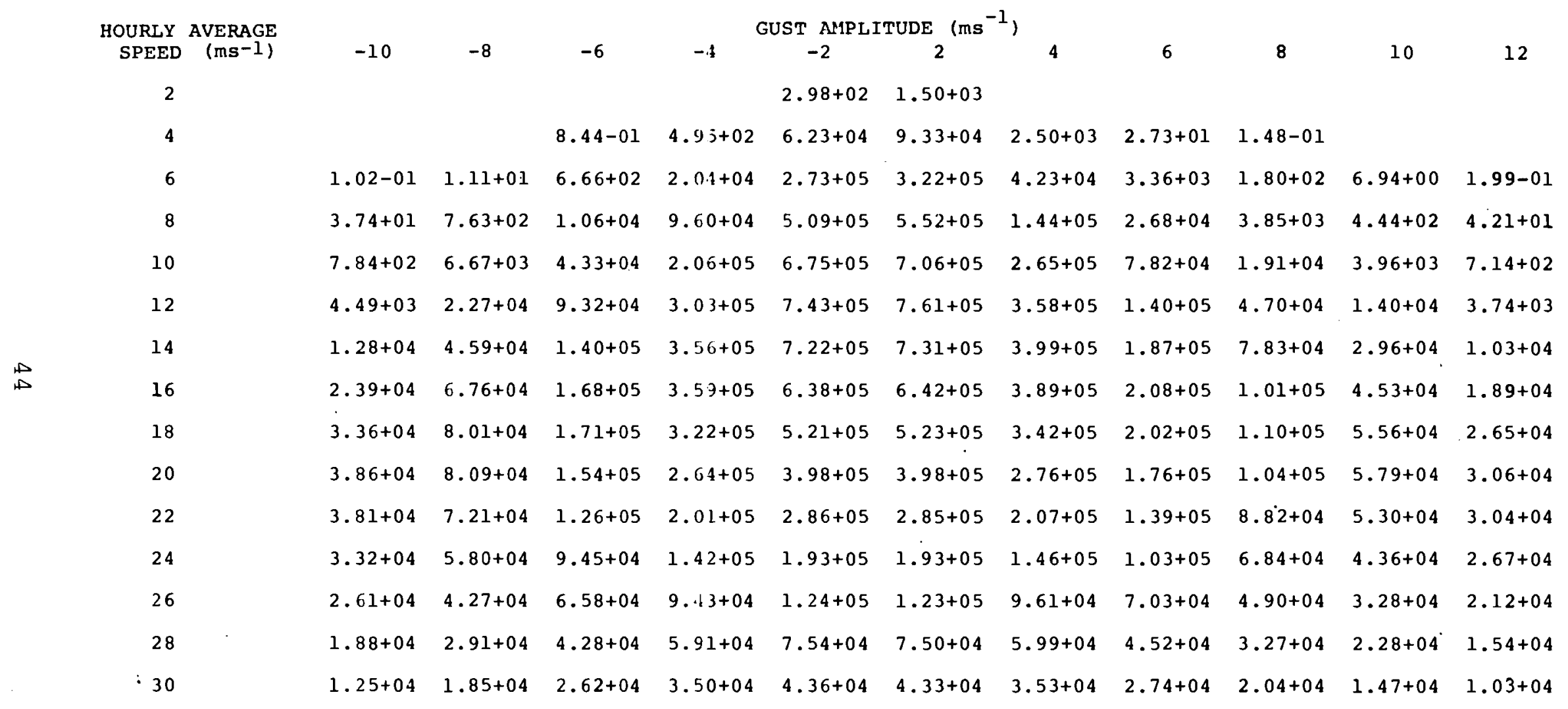


PNL

Report No.: PNL-2508

Date:

UC -60

PII DISTRIBUTION

No. of

Copies

OFFSITE

\section{A. A. Churm \\ DOE Chicago Patent Group 9800 South Cass Avenue \\ Argonne, IL 60439}

G. P. Tennyson

Department of Energy

600 E Street, N.W.

283
No. of

Copies
Washington, DC 20545

Ben Wolff

American Wind Energy Association C/o Windworks

P.0. Box 329, Route 3

Mukwonago, WI 53149

Richard Katzenberg

American Wind Energy Association

Natural Power Inc.

New Boston, NH 03070

E. J. Warchol

Bonneville Power Administration

P.0. Box 3621

Portland, OR 97225

S. J. Hightower

Bureau of Reclamation

Denver Federal Center

B1dg. 67 Code 254

Denver, CO 80225

Thomas Vonier

AIA Research Corp:

1735 New York Avenue, N.W.

Washington, DC 20006

Dr. Paul B. MacCready, Jr. AeroVironment Inc.

145 Vista Avenue

Pasadena, CA 91107

Clarissa Quinlan

Alaska State Energy Office

338 Denali Street

Anchorage, AK 99501
M. Ginosar

California Solar Energy

Commission

Energy, Resources Conservation \& Development Commission

1111 Howe Avenue, Mai1 Stop 15

Sacramento, CA 95825

Robert Ball

Center for the Environment \&

Man, Inc.

275 Windsor Street

Hartford, CT 06120 
Dr. R. J. Hawks

Clarkson College

Potsdam, NY 13676

Dr. R. N. Meroney

Colorado State University

Fort Collins, CO 80523

E. H. Gilmore

Department of Agriculture

Agriculture Research Service

Bushland, TX 79012

L. A. Liljedahl

Department of Agriculture

Agriculture Wind Energy Program

Building 001 Room 126 BARC-West

Beltsville, MD 20705

Douglas G. Fox

Department of Agrculture

Forest and Mounta in Meteorology

Rocky Mounta in Forest and Range

Experiment Station

240 West Prospect St.

Fort Collins, CO 80521

Major T. E. Kullgran

Department of the Air Force

USAF Academy

CO 80840

Jay Tappan

Department of Energy

State of Oregon

Labor \& Industries Building

Room 111

Salem, OR 97310

Harry Moses

Department of Energy

Division of Biomedical \&

Environmental Research

Mail Stop E-201

Washington, DC 20545
Carl Miner TAN-604

EG\&G Idaho, Inc.

P.0. Box 1625

Idaho Falls, ID 83401

Dr. Edgar Demeo

Electric Power Research

Institute

3412 Hillview Avenue

Palo Alto, CA 94303

Jim Lerner

Energy Resources Conservation and Development Commission

California Solar Energy Office

Mail Stop 15

Sacramento, CA 95825

Dr. W. Frost

FWG Associates, Inc.

R. R. 3 Box 331

Tuliahoma, TN 37388

L. Krawitz

General Electric Company

P.0. Box 8555

Philadelphia, PA 19101

R. C. Koch

Geomet, Inc.

15 Firstfield Road

Gaithersburg, MD 20760

C. G. Justus

Georgia Institute of

Technology

Atlanta, GA 30332

Darryl Tompkins

JBF Scientific Corporation

1925 North Lynn Street

Suite 308

Arlington, VA 22209 
Dr. J. B. Knox

Lawrence Livermore Laboratory.

University of California

P.0. Box 808

Livermore, CA 94550

M. Abbey Page

Maine Office of Energy

Resources

55 Capitol

Augusta, ME 04330

S. M. Howard

Meteorology Research, Inc.

P.0. Box 637

Altadena, CA 91001

Phillip French

NASA Scientific and Technical

Information Facility

P.0. Box 8757

Baltimore/Washington

International Airport

MD 21240

\section{R. A. Wolf}

NASA/Lewis Research Center

Mail Stop 500-201

Cleveland, $\mathrm{OH} 44135$

M. J. Changery

National Oceanic \& Atmospheric

Administration

National Climatic Center

Federal Building

Asheville, NC 28801

Ms. Peggy McDonald

N. E. Solar Energy Center

70 Memorial Drive

Cambridge, MA 02142

N. W. Edetslein

North American Weather

Consultants

Goleta, CA 93017
R. B. Corotis

Northwestern University

Evanston, IL 60201

E. W. Hewson

Oregon State University

Corvallis, OR 97331

S. C. Crow

Poseidon Research

11777 San Vicente Blvd.

Suite 641

Los Angeles, CA 90049

Dr. F. M. Vukovich

Research Triangle Institute

P.0. Box 12194

Research Triangle Park

NC 27709

Terry J. Healy

Rockwell International

Rocky Flats Plant

P.0. Box 464

Golden, CO 80401

2 R. E. Akins/J. W. Reed

Sandia Laboratories

Division 5443

P.0. Box 5800

Albuquerque, NM 87115

R. M. Traci

Science Applications, Inc.

P.0. Box 2351

La Jo71a, CA 92038

D. M. Hardy

Solar Energy Research

Insti tute

1536 Cole Blvd.

Golden, CO 80401

Or. C. M. Bhumralkar

Stanford Research

Institute, Int'1

Men 1o Park, CA 94025 
No. of

Copies
No. of

Copies

Dr. T. Wentink, Jr.

University of Alaska

Fairbanks, AK 99701

Dr. P. Yuen

University of Hawai i at Manoa

Holmes Hall 240

2540 Dole Street

Honolulu, HI 96822

C. E. Duchon

University of Oklahoma

200 Felgar Street

Norman, OK 73069

Dr. N. K. Wagner

University of Texas

Austin, TX 78712

Dr. M. Garstang

University of Virginia

Charlottesville, VA 22903

Dr. R. W. Marrs

University of Wyoming

Laramie, WY $8207 i$

Ms. Susan Hosch

Washington State Energy Office 400 East Union Ave., Ist Floor

O1ympia, WA 98504

Prof. Kent Rowe

Wichita State University

Box 444

Wichita, KS 67208
2

\section{ONSITE}

DOE Richland Operations Office

G. L. Liffick

H. E. Ransom

54

Battelle-Northwest

W. C. Cliff

R. L. Conley

J. C. Doran

R. L. Drake

C. E. Elderkin (18)

R. K. Hadlock

W. T. Pennell

E. H. Phinney

J. V. Ramsdell (20)

D. S. Renne

C. L. Simpson

L. L. Wende 11

Technical Information (5)

Technical Publications 